\title{
COVID-19 related mortality and spread of disease in long-term care: a living systematic review of emerging evidence
}

\author{
Maximilian Salcher-Konrad ${ }^{1^{*}}$, Arnoupe Jhass, ${ }^{2,3}$ Huseyin Naci, ${ }^{4}$ Marselia Tan, ${ }^{1}$ Yousef El-Tawil, ${ }^{4}$ \\ Adelina Comas-Herrera ${ }^{1}$
}

\footnotetext{
${ }^{1}$ Care Policy and Evaluation Centre (CPEC), London School of Economics and Political Science

${ }^{2}$ Research Department of Primary Care \& Population Health, University College London

${ }^{3}$ Institute of Health Informatics, University College London

${ }_{4}^{4}$ Department of Health Policy, London School of Economics and Political Science

* Corresponding author: m.salcher@lse.ac.uk; London School of Economics and Political Science, Houghton Street, London WC2A 2AE, United Kingdom.
}

\begin{abstract}
Background: Policy responses to mitigate the impact of the COVID-19 pandemic on long-term care (LTC) require robust and timely evidence on mortality and spread of the disease in these settings. The aim of this living systematic review is to synthesise early international evidence on mortality rates and incidence of COVID-19 among people who use and provide LTC.
\end{abstract}

Methods: We report findings of a living systematic review (CRD42020183557), including studies identified through database searches up to 26 June 2020. We searched seven databases (MEDLINE; Embase; CINAHL Plus; Web of Science; Global Health; WHO COVID-19 Research Database; medRxiv) to identify all studies reporting primary data on COVID-19 related mortality and incidence of disease among LTC users and staff. We excluded studies not focusing on LTC. Included studies were critically appraised and results on number of deaths and COVID-19 related mortality rates, case fatality rates, and excess deaths (co-primary outcomes), as well as incidence of disease, hospitalisations, and ICU admissions were synthesised narratively.

Findings: A total of 54 study reports for 49 unique primary studies or outbreak reports were included. Outbreak investigations in LTC facilities found COVID-19 incidence rates of between 0.0\% and $71.7 \%$ among residents and between $0.4 \%$ and $64.0 \%$ among staff at affected facilities. Mortality rates varied from $0.0 \%$ to $17.1 \%$ of all residents at outbreak facilities, with case fatality rates between $0.0 \%$ and $33.7 \%$. In included studies of outbreaks, no LTC staff members had died.

Studies of wider LTC populations found that between $0.4 \%$ and $40.8 \%$ of users, and between $4.0 \%$ and $23.8 \%$ of staff were infected, although the generalisability of these studies is limited.

There was limited information on the impact of COVID-19 on LTC in the community.

Interpretation: Long-term care users have been particularly vulnerable to the COVID-19 pandemic. However, we found wide variation in spread of disease and mortality rates between outbreaks at individual LTC facilities. Further research into the factors determining successful NOTE: This preprint reports new research that has not been certified by peer review and should not be used to guide clinical practice. 
medRxiv preprint doi: https://doi.org/10.1101/2020.06.09.20125237; this version posted August 1,2020. The copyright holder for this preprint (which was not certified by peer review) is the author/funder, who has granted medRxiv a license to display the preprint in It is made available under a CC-BY-NC-ND 4.0 International license .

prevention and containment of COVID-19 outbreaks is needed to protect long-term care users and staff.

Funding: This work was partially conducted as part of the "Strengthening responses to dementia in developing countries" (STRiDE) project, supported by the UK Research and Innovation's Global Challenges Research Fund (ES/Po10938/1). The funders had no role in the design and execution of this study, interpretation of its results, and decision to submit this work to be published. 


\section{Introduction}

The coronavirus disease 2019 (COVID-19) pandemic has taken a substantial morbidity and mortality toll on the world. ${ }^{1}$ Over the course of the evolving pandemic, public attention in some countries has shifted towards long-term care facilities as "ground zero". ${ }^{2}$ Early evidence on risk factors for severe outcomes suggested that residents of long-term care facilities, such as nursing homes and residential care facilities for people who need medical support or support in their activities of daily living, may be particularly vulnerable. Studies have shown that older people and those with underlying health conditions, including hypertension, diabetes, cardiovascular disease, chronic lung disease, obesity, and cancer, are more likely to experience severe outcomes after contracting the disease. ${ }^{3}$ Importantly, case series from China, Italy, the United States (US), and the United Kingdom (UK), have shown higher mortality rates among older people who contract COVID-19. ${ }^{4,5,6,7}$ Official figures showed that a substantial proportion of COVID-19 related deaths - more than $50 \%$ of all deaths in many high-income countries - is concentrated among long-term care users. ${ }^{8}$ While older people and those with chronic conditions would already have higher mortality rates in the absence of a pandemic, a modelling study for the United Kingdom has shown that excess deaths due to COVID-19 are likely to be concentrated among older people. ${ }^{9}$ It has also been suggested that older age and some chronic conditions were associated with an increased risk of infection with SARS-CoV-2, the virus causing COVID$19 .^{8}$

While the combination of a population of older people with underlying health conditions living in close proximity to each other suggests the long-term care sector to be at particularly high risk, specific evidence on COVID-19 infections and associated deaths in this setting was initially slow to emerge. An early rapid review on deaths in care homes conducted in mid-April 2020 identified only three studies on infection rates and COVID-19 incidence and mortality in longterm care homes (all from the US). ${ }^{8}$ These studies showed wide variation in the proportion of residents and staff being infected (with the majority of people who contracted COVID-19 asymptomatic at the time of testing), in the spread of the disease between different care homes, and in case fatality rates among nursing home residents, which were reported to be as high as $33 \% .^{10,11,12}$ As the pandemic continues to spread, more evidence about the spread and impact of COVID-19 in long-term care settings is emerging, including outbreak reports and studies about infection rates and outcomes among those receiving long-term care services (long-term care users) and those providing them (long-term care staff), including both for institutional settings and community-based services. Indeed, the number of records in PubMed retrieved through a combination of search terms for COVID-19 and long-term care increased by approximately 100 records per week from the end of April to the end of June.

Given the vulnerability of the population relying on long-term care services and the potentially large burden of COVID-19 in this sector, timely and evidence-based policy responses are required. We therefore aimed to systematically collate and synthesise available and newly emerging evidence on the number of long-term care users and staff who contract COVID-19 and experience severe outcomes, including death, and the spread of disease in long-term care settings. 


\section{Methods}

We conducted a systematic review of available evidence on COVID-19 infection rates and mortality among users and providers of long-term care services (PROSPERO: CRD42020183557). Due to the rapidly evolving nature of the situation and an expected increase in research focusing on COVID-19 in long-term care, database searches will be updated continuously, and findings incorporated as a living systematic review. The reporting of this review is PRISMA-compliant (see supplemental file). ${ }^{13}$

\section{Search Strategy E Selection Criteria}

Potentially eligible studies were identified through systematic searches of seven electronic databases (MEDLINE, Embase, CINAHL plus, Web of Science, Global Health, the World Health Organization's COVID-19 Research Database, medRxiv). Search terms were based on published search blocks for COVID-19 related studies and were adapted to each database (see supplemental file). ${ }^{14,15}$ We included full study reports and research letters published in peerreviewed journals or on pre-print servers since 1 January 2020 in order to capture newly emerging evidence pertinent to the COVID-19 pandemic. Initial database searches were conducted on 15 May 2020 and updated weekly up to 26 June 2020.

Inclusion criteria were defined following the CoCoPop (Condition, Context and Population) framework, as recommended by the Joanna Briggs Institute for systematic reviews of prevalence and incidence. ${ }^{16}$ Studies were eligible for inclusion if they reported primary data on COVID-19 related mortality (including mortality rate among the population of interest, case fatality rate (CFR), and excess deaths compared to previous periods) or spread of COVID-19 among users and staff of long-term care services. Long-term care services included both institutional and community (i.e., care provided in the homes of patients) settings. We excluded studies that focused on COVID-19 mortality and infection rates in non-long-term care settings, studies of infectious disease outbreaks other than COVID-19, modelling studies, as well as opinion pieces and review articles that did not report original data. We had previously included reports of official figures of COVID-19 deaths and the proportion of long-term care users among them but decided to exclude these figures as more evidence from primary research studies became available. Official figures are summarised by members of our group in separate reports. ${ }^{8}$

Title and abstract screening, as well as full text review was undertaken by three reviewers (AJ, MS-K, and MT). To ensure consistency, all studies deemed eligible for inclusion were again reviewed by one reviewer (MS-K). Records reporting on the same study or outbreak were combined.

\section{Data Extraction E Synthesis}

A standardised template was used to extract data at the study level, including information on study design; care setting (institutional vs. community); how COVID-19 was diagnosed and confirmed; baseline characteristics of participants; absolute number of deaths and mortality rates for people with confirmed and suspected COVID-19; CFRs; excess deaths; absolute 
numbers and rates of confirmed and suspected COVID-19; and rates of hospitalisation and intensive care unit (ICU) admissions among people with confirmed and suspected COVID-19. All study participant characteristics and outcomes data were extracted separately for long-term care users and staff. For rates, we also recorded how numerator and denominator were defined, as well as the follow-up time over which outcomes were measured.

Based on extracted data, we calculated the mortality rate directly attributable to COVID-19 (all deaths among those who contracted COVID-19/all long-term care users or staff), CFR (all deaths among those who contracted COVID-19/all long-term care users or staff who contracted COVID-19), incidence of COVID-19 (all those who contracted COVID-19/all long-term care users or staff), and incidence of hospital and ICU admissions (all hospital or ICU admissions/all long-term care users or staff who contracted COVID-19). Due to heterogeneity in the definitions of numerators, denominators, and follow-up times across included studies, data were not pooled. Instead, results are summarised narratively and presented in tables, including information on sample characteristics, follow-up time, and case definitions, as appropriate. Where studies reported on overlapping populations, we gave preference to those with larger sample sizes and longer follow-up times.

In addition to the pre-specified outcomes above, we extracted information on the proportion of asymptomatic people with COVID-19 at time of testing, and findings of studies comparing outcomes in long-term care users to others.

\section{Critical Appraisal}

The quality of included studies reporting figures relating to mortality rates, CFR, or disease incidence were assessed using the Joanna Briggs Institute critical appraisal tool for prevalence studies. ${ }^{17}$ The tool includes nine questions about the appropriateness of the sampling frame, sampling of participants, sample size, description of study setting and participants, data analysis, identification of cases, measure of disease, statistical analysis, and response rate. We summarised appraisals as the number of items that were deemed appropriate for each study.

We did not assess risk of bias across studies.

\section{Results}

The first report of this living systematic review was published on 9 June $2020,{ }^{18}$ and an updated version on 29 June 2020 . Since then, 21 additional studies were included, leading to a total of 54 study reports for 49 unique studies or outbreak reports (Figure 1).7,10,11,12,19,20,21,22,23, $24,25,26,27,28,29,30,31,32,33,34,35,36,37,38,39,40,41,42,43,44,45,46,47,48,49,50,51,52,53,54,55,56,57,58,59,60,61,62,63,64,65,66,67,68$

An overview of study characteristics is provided in Table 1. Twenty reported on individual outbreaks, while the rest reported on wider populations. Included studies were conducted in 14 countries (20 in the United States, six each in Spain and the United Kingdom, three each in Canada and South Korea, two each in Belgium and France, and one each in Germany, Hong Kong, Hungary, Ireland, Israel, the Netherlands, and Poland). All included studies except for 
medRxiv preprint doi: https://doi.org/10.1101/2020.06.09.20125237; this version posted August 1, 2020. The copyright holder for this preprint (which was not certified by peer review) is the author/funder, who has granted medRxiv a license to display the preprint in It is made available under a CC-BY-NC-ND 4.0 International license .

three were exclusively conducted in institutional care settings. Three studies reported on homebased or community-based care.

\section{Evidence on disease incidence in institutionalised long-term care settings}

Evidence on the spread of disease within institutional long-term care settings was available from 25 studies, ${ }^{20,21,22,26,29,30,31,34,36,39,41,45,47,48,51,52,56,58,60,62,63,64,66,67,68}$ including 17 studies reporting the number of people who contracted COVID-19 in facilities facing potential outbreaks (Table 2) and eight studies reporting relevant figures among regional or national populations of longterm care facilities (Table 3 ).

The incidence rate for cohorts of residents at long-term care institutions where an outbreak occurred varied widely. The lowest estimates was $0 \%$ over a three-week period and was observed in a South Korean long-term care hospital, where an infected care worker had been working throughout the facility for two days while symptomatic. ${ }^{34}$ Following the diagnosis of the index case, exposed care workers were quarantined at home, while remaining staff who continued to work were quarantined in a hotel. Considerably higher incidence rates of between $40.3 \%$ and $71.7 \%$ were reported from outbreaks in facilities in the US, UK, and France.

The incidence rate for cohorts of long-term care staff at outbreak facilities was overall lower compared to residents. Among nine studies testing all or close to all staff members, the rate of infections was generally below $10 \%$, with the exception of one French study reporting a rate of $\mathbf{2 3 . 5} \%$ over six weeks (during weekly testing, no new people with COVID-19 were detected after the first two weeks) and a US study reporting a rate of $19.9 \%$ over six weeks across four outbreak facilities. ${ }^{51,64}$ Another point-prevalence study from the UK found that $4.1 \%$ of a sample of asymptomatic staff representing various roles across three nursing homes (including care workers as well as kitchen staff, administrators, and maintenance personnel) tested positive. ${ }^{30}$ The rate of infection was higher for the remaining three studies, but this included two where testing was only conducted for some staff members, and one report of an outbreak that did not provide details on testing.

Population-wide estimates of infection ranged from $0.4 \%$ to $40.8 \%$ for different populations of LTC users (Table 3). Only three studies were based on systematic testing, including the two studies reporting the highest rates of infection. However, some caveats about their findings should be noted. Kennelly et al. only included nursing homes in Dublin and Eastern Ireland that reported outbreaks and responded to their survey, thereby excluding more than half of all nursing homes in their sampling frame. ${ }^{56}$ Borras-Bermejo et al. tested residents and staff of 69 nursing homes in Barcelona but excluded those who already had a confirmed COVID-19 diagnosis..$^{22}$ Rudolph et al. tested residents of Veteran Affairs community living centres in the US (predominantly male) but excluded those who had already been tested (due to showing symptoms, or prior to admission to a facility) and those who did not participate in universal testing. ${ }^{66}$

Two of the studies based on systematic testing also reported population-wide prevalence among LTC staff, with $23.8 \%$ of staff at nursing homes in Dublin and Eastern Ireland testing positive 
and $15.2 \%$ of staff at nursing homes in Barcelona. ${ }^{52,56}$ Another Spanish study found that $9.5 \%$ of health care workers in nursing homes in the region of Leon had antibodies, but was likely to underestimate true prevalence due to the testing strategy. ${ }^{8}$ Finally, a survey among facilities providing care to people living with dementia and older people in England found that $4.0 \%$ of staff members had contracted confirmed COVID-19 at some point during the pandemic (no systematic testing was in place at the time of the survey). ${ }^{62}$

Data on asymptomatic residents and staff who tested positive for COVID-19 was extracted from 13 studies (Table 4). ${ }^{22,26,30,31,35,36,39,40,48,51,52,56,63}$ Definitions of symptomatic cases differed (see lists of symptoms in the table), as did the number of identified cases, leading to a range of asymptomatic people who contracted COVID-19 at the time of testing between $7 \%$ and $78 \%$ among long-term care residents, and between $24 \%$ and $100 \%$ among staff.

\section{Evidence on case fatality rates in institutionalised long-term care settings}

CFR is the proportion of people with confirmed COVID-19 who die. CFRs for 11 studies of all people at long-term care institutions facing outbreaks (including COVID-19 positive and negative residents and staff) are summarised in Table $5{ }^{10,22,26,29,30,36,39,41,48,51,63}$ while CFRs for seven studies of COVID-19 positive populations are described further down. ${ }^{23,25,32,38,60,67,68}$

For most studies included in Table 5, the source population for the identification of people with COVID-19 were all or close to all (>90\%) residents or staff at long-term care institutions where an outbreak occurred. The CFR among long-term care users for these studies ranged from o\% to $33.7 \%$, with differences in follow-up time between one and 12 weeks. The CFR among longterm care staff was o\% in all included studies. These figures of outbreaks at individual facilities are complemented by a survey of nursing homes experiencing outbreaks in Dublin and Eastern Ireland, which found a CFR of $25.8 \%$ for residents with confirmed COVID-19. ${ }^{56}$

Not included in Table 5 are CFRs reported by seven studies for which the source population consisted exclusively of people who contracted COVID-19. ${ }^{23,25,32,38,60,67,68}$ Due to the absence of systematic testing, these studies tended to only include symptomatic people in the denominator, resulting in higher CFRs compared to studies based on systematic testing, as described below.

Prieto-Alhambra et al. found the 30-day mortality rate among 10,795 nursing home residents who were registered with a clinical or lab-confirmed COVID-19 diagnosis in a regional primary care database in Catalonia (Spain) to be $25.3 \%$ (95\% CI 24.2-26.4\%)..$^{8}$ This was considerably higher compared to the 30-day mortality rate for all other people with COVID-19 in the database (4.0\%, 95\% CI 3.9-4.2\%), although these findings were not adjusted for age and underlying chronic conditions.

Baker et al. found that $40.7 \%$ of 60 nursing or residential home residents with lab-confirmed COVID-19 who were admitted to a teaching hospital in Newcastle (UK) died within a 28-day period. ${ }^{23}$ Compared to non-care home residents, the unadjusted odds ratio for death was 6.19 (95\% CI 3.32-11.8). 
De Smet et al. report that 52\% of COVID-19 patients at a geriatric department were admitted from long-term care facilities, and the CFR for those was $28.6 \% .^{25}$

The source population was unclear for Kemenesi et al., which reported the number of deaths among all nursing home residents with confirmed COVID-19 in Hungary to be $4 \% .{ }^{32}$ It is unclear how people contracting COVID-19 in nursing homes were identified.

Similarly, the CFR of $27.8 \%$ in Brown et al. was calculated across all nursing homes in the province of Ontario, Canada, but this was based on reporting of cases to the authorities, rather than on systematic testing of all residents. ${ }^{68}$

The CFR was $14.3 \%$ for seven people with confirmed COVID-19 among those receiving visiting medical care at assisted living facilities in Ohio (US). ${ }^{60}$

Finally, Verbeek et al. report that 16 of 29 people with confirmed COVID-19 at 26 nationally representative nursing homes in the Netherlands died, but did not provide a time period for these figures (CFR 55.2\%). ${ }^{67}$

\section{Evidence on mortality rates in long-term care settings}

Table 6 presents mortality rates for people who contracted COVID-19 from 11 studies of outbreaks at long-term care institutions. ${ }^{26,29,30,34,36,39,41,48,51,54,63}$ The source populations for these studies are all or close to all (>90\%) residents or staff at long-term care institutions where an outbreak occurred. For these studies, the mortality rate for all or nearly all residents over a 1-to12-week follow-up period was between $0.0 \%$ and $17.1 \%$. Due to limited data on source population and causes of deaths, we did not include an outbreak report from another skilled nursing facility in the US in this Table..$^{\circ}$ Assuming full occupancy at the 150-bed facility, and all 29 reported deaths having been caused by COVID-19, the mortality rate would be $19.3 \%$ of all residents over a 3.5-week period.

There were two studies reporting on mortality among all staff members who were screened, and in both of these outbreaks, no member of staff had died after follow-up periods of 3 and 9.5 weeks, respectively. ${ }^{29,34}$

Information on excess deaths among long-term care residents was only available from two studies in the London area (UK). One study of outbreaks in four nursing homes estimated an increase in all-cause mortality by $203 \%$ for a two-month period compared to the average of the preceding two years. ${ }^{30}$ In contrast, a study of three different homes in the London area found the number of deaths over 12 weeks comparable to average mortality rates from the previous five years. $4^{8}$

Three studies reported the number of COVID-19 related deaths among wider populations of long-term care users. The proportion of all nursing home residents who died having contracted COVID-19 was $1.8 \%$ across all nursing homes in Ontario, Canada $(1,452$ deaths among 78,607 
residents), ${ }^{68}$ and $0.8 \%$ across 26 nursing homes representing all regions in the Netherlands (16 deaths among 2,011 residents). ${ }^{67}$ However, neither of the two studies was based on systematic testing of residents and both could have underestimated the true number of residents dying having contracted the disease. A considerably higher proportion was reported for a sample of 21 nursing homes in Eastern Ireland and Dublin (10.5\% of all residents over a 12-week period)..$^{56}$ However, this study was limited to nursing homes with active outbreaks and was missing information from approximately one third of homes in the sampling frame.

\section{Evidence on hospitalisations and ICU admissions from institutionalised long-term care settings}

Nine studies provided information on the rate of hospitalisations among long-term care residents with COVID-19 diagnosis, ${ }^{10,22,29,38,39,40,43,60,63}$ (Table 6). Hospitalisation rates for longterm care residents varied between $0.0 \%$ and $54.4 \%$ for follow-up periods of between three and 14 weeks.

Hospitalisation rates for long-term care staff with COVID-19 diagnosis were $0.0 \%$ and $6.0 \%$ in two studies in US skilled nursing facilities.

Two studies reported the number of people who contracted confirmed COVID-19 among longterm care users who were admitted to the ICU. Arons et al. report that 5.3\% of 48 nursing home residents with a positive PCR test were admitted to an ICU over a 3.5-week period. ${ }^{22}$ Roxby et al. report that none of the four residents at an assisted living facility with positive PCR test were admitted to an ICU over a three-week period. ${ }^{39}$

Evidence on impact of COVID-19 on people who use long-term care community services

Only three included studies focused on people receiving long-term care in the community.

One US study reported on people with intellectual and developmental disability receiving longterm care services in the community, including in their family homes, foster care homes, or group homes (although some also lived in intermediate care facilities). ${ }^{46}$ Among a total population of 11,540 individuals, there were 66 with confirmed COVID-19 (o.6\%) over a 100-day period. Only symptomatic people were tested. The CFR among people with confirmed COVID19 was $4.5 \%$, and $22.7 \%$ required hospitalisation.

The same organisation providing services to people with intellectual and developmental disability also reported on their experience providing home health and personal care to older people. ${ }^{61}$ Over 100 days, 67 people who contracted confirmed COVID-19 were detected (less than $0.3 \%$ of all clients). 47 of 67 were detected while living in the community. Among these, 17 required hospitalisation and 13 died.

The third study reported a total of 84 people with confirmed or suspected COVID-19 among the users of a memory unit and day care centre for people with cognitive disorders in Barcelona (Spain), with a CFR of $44.1 \% .{ }^{49}$ 
Evidence on outcomes in long-term care residents compared to others

Seven of the included studies compared outcomes in people who contracted COVID-19 between long-term care users and others. These studies generally found that long-term care users had worse outcomes, including higher 28-day-mortality (unadjusted odds ratio for death of nursing home or residential home residents admitted to hospital compared to non-residents: $6.19,95 \%$ CI 3.32-11.8), ${ }^{23} 30$-day-mortality (25.3\%, 95\% CI 24.2-26.4\%, among nursing home residents who contracted COVID-19 and were registered in a primary care database compared to $4.0 \%, 95 \%$ CI 3.9-4.2\%, among all other people with COVID-19 in the database), $3^{8}$ and overall mortality (incidence rate ratio for COVID-19 mortality comparing Ontario long-term care residents to community-living adults 70 years and older: $13.1,95 \% \mathrm{CI}$ 9.9-17.3), ${ }^{27}$ as well as increased risk of complicated disease (odds ratio for deteriorating disease, admission to ICU, or death, comparing nursing home residents to non-residents over 65 years of age: 2.48 , 95\% CI 1.294.65). ${ }^{43}$ Bhatraju et al. report that, among 24 patients admitted to the intensive care units of nine hospitals in the Seattle area (US), six (25\%) were residents of skilled nursing facilities. ${ }^{7}$

Two studies did not find a statistically significant association between long-term care users and worse COVID-19 outcomes. De Smet et al. found that short-term mortality was not associated with long-term care residence in a cohort of COVID-19 patients at a geriatric department. ${ }^{25}$ Palaiodimos et al. did not find that nursing home residents fared worse than communitydwelling patients in a retrospective cohort study of the first 200 lab-confirmed COVID-19 cases in a teaching hospital in New York, US. ${ }^{37}$ There was no statistically significant difference between community-based and skilled nursing facility based patients for in-hospital mortality (OR 0.90, 95\% CI o.42-1.91; $\mathrm{p}=0.779$ ), increasing oxygen requirements (OR 1.14, 95\% CI 0.592.21; $\mathrm{p}=0.701)$, and intubation $(1.39,95 \% \mathrm{CI} 0.59-3.27 ; \mathrm{p}=0.446)$.

Evidence on burden of disease in the long-term care sector

Complementing studies of individual outbreaks, 14 studies provided evidence on the extent to which long-term care users are affected by the COVID-19 pandemic. These studies varied widely in their sampling frame (ranging from nationwide figures to single-centre case series of COVID19 patients), and findings therefore need to be viewed in this context.

Kemenesi et al. report that in Hungary, as of 18 April 2020, $11 \%$ of all people with laboratoryconfirmed COVID-19 in the country came from social homes, all of which were adult nursing homes. ${ }^{32}$ Similarly, Raciborski et al. report that $13.3 \%$ of all people with laboratory-confirmed COVID-19 in Poland up to 30 April 2020 were in nursing homes. ${ }^{65}$ Prieto-Alhambra et al. found that $8.9 \%$ of 121,263 people with COVID-19 registered in primary care records in Catalonia (Spain) were nursing home residents. ${ }^{38}$

Brown et al. found that $6.6 \%$ of all nursing homes in Ontario (Canada) had at least one person who contracted COVID-19 between 29 March and 20 May 2020.42,68 $86 \%$ of cases were concentrated in only $10 \%$ of nursing homes. 
Li et al. also found infections in nursing homes in Connecticut (US) to be concentrated. ${ }^{57} 50 \%$ of 215 surveyed nursing homes reported any person who contracted COVID-19. While the average number of infected people was eight per home, $29 \%$ of homes reported more than ten. Lower staffing levels, higher quality ratings, and higher concentrations of Medicare or ethnic minority residents were predictive of higher numbers of infected people. Similarly, He et al. found that $35 \%$ of nursing homes in California (US) had at least one person who contracted the disease, with nursing home ratings and proportion of residents from ethnic minority groups predictive of COVID-19 infections and deaths. ${ }^{55}$ Across the US, Abrams et al. found that 31.4\% of 9,395 surveyed nursing homes had at least one documented person with COVID-19. ${ }^{19}$ Mills et al. report that $1.3 \%$ of all homes for people with intellectual and developmental disability in the US supported by their organisation (including community-based sites, such as family and foster care homes, as well as institutional homes) had at least one person with confirmed COVID-19 over a 10o-day period, although testing was limited to symptomatic individuals. ${ }^{4}$

The Office for National Statistics (ONS) for England conducted a large survey and found that $56 \%$ of all care homes catering to people living with dementia and older people had at least one person who contracted confirmed COVID-19. ${ }^{62}$ Higher levels of infection among residents were associated with prevalence of infection among staff, the use of bank or agency nurses, and different regions. In line with this finding about regional variation, Brainard et al. report that only 25 of 248 care homes in Norfolk (UK) had any people who contracted COVID-19.53 Detection of any cases was associated with the number of staff not directly involved in personal care.

Cabrera et al. report the results of systematic testing of all residents and staff in care homes in Galicia (Spain) and found the prevalence of confirmed COVID-19 to be 3.4\% (no breakdown of these figures by long-term care users and staff was provided). ${ }^{44} 263$ of 306 care homes did not have a single person with confirmed COVID-19.

Kim \& Jiang found that three of the 12 largest clusters in South Korea were related to long-term care facilities, including two nursing homes and one psychiatric ward of a long-term care hospital. ${ }^{33}$ Das and Gopalan found that 46 out of 3,299 (1.4\%) patients with confirmed COVID19 in South Korea from 20 January to 30 April 2020 had been exposed at nursing homes (no information about whether these were residents, staff, or visitors). ${ }^{24}$

Gold reports that 20 of 305 (6.6\%) of all hospitalised patients with laboratory confirmed COVID in Atlanta and Southern Georgia (US) were residents in a long-term care facility (study period: 1 to 30 March 2020). ${ }^{28}$ Also reporting on a cohort of hospitalised patients, Martin-Jimenez et al. found that $16.3 \%$ of deceased COVID-19 patients at their hospital in Madrid (Spain) were nursing home residents.

\section{Discussion}

We report updated findings of a living systematic review of the spread of COVID-19 and outcomes in long-term care settings. Our findings based on review of 49 studies can be summarised as follows. First, outbreak reports and studies of wider populations of long-term 
care users showed the severe impact of the pandemic on this group. Outbreaks at long-term care facilities can affect more than thirds of residents and lead to the deaths of a little under one fifth of residents. Excess risk of severe outcomes for long-term care users after contracting COVID-19 was also found in several studies (including increased risk of death), although not all studies accounted for case mix, and other studies did not find increased risk for long-term care users. Second, included studies showed substantial variation in how widely the disease spread among both residents and staff, and how many residents died as a result of COVID-19 outbreaks in long-term care facilities. While it is currently unclear what is driving the variation in spread of disease and outcomes, some outbreaks have been contained successfully, suggesting that future research should explore the source of this variation to provide urgently needed evidence to better manage COVID-19 in long-term care. Some of the included studies also provided early evidence on characteristics of nursing homes predictive of higher numbers of people contracting COVID-19, which will need to be substantiated through future research. Evidence on impact of COVID-19 on long-term care in the community is still scarce, even though this represents a group that is potentially highly vulnerable to infection (as they rely on care from others) and at risk of severe outcomes. ${ }^{69}$ Third, a substantial proportion of people with COVID19 detected during systematic screening of residents (as many as $75 \%$ ) and staff (up to $100 \%$, although case numbers were very low) of long-term care facilities were asymptomatic at the time of testing, casting doubts over the appropriateness of symptoms-based strategies in this setting. Finally, reporting standards of included studies were variable and often poor, highlighting the need to harmonise research practices and reporting standards in this body of fast-evolving literature.

\section{Impact of COVID-19 on the long-term care sector}

The findings of this living systematic review underline the urgent need for decisive policy action to tackle the COVID-19 pandemic in the long-term care sector. The combination of older, chronically multimorbid people, living in close proximity to each other has contributed to this population being particularly vulnerable to the COVID-19 pandemic. This vulnerability has been mirrored in official figures which show that deaths in long-term care users now make up more than $50 \%$ of all COVID-19 related deaths in at least five countries, and more than $30 \%$ in 16 of 19 countries reporting relevant data. ${ }^{8}$

Emerging evidence summarised in this review also shows potentially excessive risk of severe outcomes, including a higher risk of death, among long-term care residents compared to nonlong-term care residents of similar age. While official deaths data for care homes in most countries only includes people who either tested positive or had COVID-19 mentioned in the death certificate, data from England and Wales shows that the number of excess deaths of care home residents during the pandemic (compared to the number of deaths in the same period in previous year) was almost double the number of deaths that had been registered as being linked to COVID-19. ${ }^{8}$ Error! Bookmark not defined. This suggests that current official estimates of the mortality impact of COVID-19 in care homes in most countries may underestimate the full impact of the pandemic, be it because of lack of attribution of deaths to COVID, or because of other indirect effects such as reduced access to usual health care for non-COVID conditions. 
This evidence highlights the need to develop targeted policies to both prevent outbreaks in long-term care settings, and to manage them effectively once they occur. In many countries, long-term care was not a priority in the early stages of the pandemic. In the UK, whilst policymakers had been aware of this risk early on in the pandemic, ${ }^{70}$ inadequacies in the testing strategy and a focus on ensuring bed capacity in the secondary care sector is likely to have undermined mitigation of the spread in care homes. Until 16 April 2020, three days after the peak in daily deaths, it was still possible for UK hospitals to send residents back to their care homes without having to test them for COVID-19. ${ }^{71}$

However, policymakers are increasingly aware of the scale of the problem in long-term care and starting to develop responses. For example, the WHO European Region Office has developed a list of ten policy objectives to tackle COVID-19 in long-term care, starting with the maintenance of long-term care services during the pandemic. ${ }^{72}$ This was recently expanded and updated by the WHO. ${ }^{73}$ Individual countries have developed their own set of policy responses, including implementing national task forces to coordinate responses in long-term care, the use of disease surveillance tools to monitor outbreaks in care homes and deployment of rapid response teams to manage them, reducing occupancy in care homes, and policies to increase the number of available staff. ${ }^{74}$ Other responses were aimed at preventing the disease entering care homes, including isolation of care home residents, restrictions or banning of visits, measures to reduce the risk of disease spreading through staff, and quarantining of residents discharged from hospital upon re-entering the care home. Importantly, as the pandemic continues over a prolonged period, attention will need to be paid to ensure continuing care and maintaining the health and wellbeing of both long-term care users and providers.

\section{Variation in infection rates and outcomes across countries and individual facilities}

This review has shown considerable variation in the number of long-term care users and staff who contract the disease after an outbreak in a facility. In some cases, more than half of the resident population was infected. In other cases, outbreaks were contained to low numbers or even preventing a single confirmed infection among residents. Included studies were not designed to test the effectiveness of different strategies to prevent or contain outbreaks, leaving open questions about the factors driving the observed variation. Possible explanations for comparatively low infection rates in individual outbreaks include decisive action to isolate potentially infected staff members and removing people with confirmed COVID-19 from the facility, ${ }^{34}$ cohorting of infected residents, ${ }^{26,29}$ weekly serial facility-wide testing, ${ }^{26}$ as well as hygiene measures and comparatively spacious and more spread-out residents in an assisted living facility (compared to a nursing home). ${ }^{39}$ We aim to examine these factors in more detail in a living systematic review of COVID-19 interventions in long-term care parallel to this one. In addition to evaluating the effectiveness of different strategies in containing outbreaks, their impact on the wellbeing of long-term care users and staff should be assessed.

It will be important to design such studies with scientific rigour in order to provide meaningful and generalisable evidence to guide decision making. The case of experimental administration of post-exposure prophylaxis hydroxychloroquine for patients and staff at a long-term care facility in South Korea highlights the need for methodologically robust studies. In the South 
medRxiv preprint doi: https://doi.org/10.1101/2020.06.09.20125237; this version posted August 1, 2020. The copyright holder for this preprint (which was not certified by peer review) is the author/funder, who has granted medRxiv a license to display the preprint in

It is made available under a CC-BY-NC-ND 4.0 International license .

Korean example, lack of a control group made it impossible to attribute the success in containing the outbreak (no patient and only one staff member other than the index case were infected over a 2-week period) to post-exposure prophylaxis. ${ }^{34}$ In the meantime, a randomised controlled trial was published and showed no efficacy of hydroxychloroquine prophylaxis after exposure to COVID-19, ${ }^{75}$ making it appear more likely that strict isolation measures put in place at the South Korean facility contributed to containing the virus.

A strategy that has increasingly attracted attention is systematic screening of residents and staff at affected facilities. Our review underlines the importance of diagnostic testing as compared to symptoms-based screening. Several included studies reported the number of infected people detected through RT-PCR testing who were asymptomatic at the time. Due to the range in the number of people who contracted COVID-19 in these studies (4-710) it was difficult to infer a reliable proportion of those residents that were asymptomatic and yet were found to be COVID19 positive on RT-PCR testing, but included studies suggest that this could be a substantial minority or even the majority of infected residents (range of asymptomatic cases among residents at time of testing, $7-78 \%$ ). For care home staff, the small numbers and sampling methods to identify people with confirmed COVID-19 made it impossible to make robust inferences about the numbers of asymptomatic employees. Further information about this would warrant a more systematic testing strategy across all care home workers and residents. Indeed, such nationwide comprehensive testing of the care home population including staff is being conducted in Belgium, showing that $74 \%$ of residents who contracted COVID-19 and $76 \%$ of staff who contractred COVID-19 were asymptomatic at the time of testing. ${ }^{76}$

Some of the included studies also highlighted that people with asymptomatic infections may develop symptoms within a period of about one week. ${ }^{10,22,26}$ Future studies should plan to follow up identified people with COVID-19 to better understand symptoms and apply a more robust definition of what constitutes symptomatic. Whilst there is seemingly broad agreement with regards to respiratory symptoms, two studies did not consider gastrointestinal symptoms (anorexia, diarrhoea, abdominal pain, vomiting) within their definition of symptomatic. Consensus may also be needed on a definition of fever; it was interesting to note that two of the included studies in this review defined fever at 37.3 and 37.8 , respectively. ${ }^{22,36}$

\section{Improvements to reporting of outbreaks}

Lack of common standards in the reporting of outcomes has long been recognised as a major challenge for synthesising research findings. ${ }^{77}$ In this systematic review, substantial differences across the included set of studies precluded a quantitative synthesis of results. Studies differed in how testing was conducted (comprehensive testing vs. convenience samples; varying time periods over which outcomes data was collected, including infections). We were also unable to ascertain the homogeneity of different populations due to a lack of reporting of their characteristics. For example, some of the outbreak investigation reports failed to report characteristics of long-term care residents, such as mean age, sex distribution, comorbidities, and ethnicity. In other studies, it was sometimes unclear whether all long-term care users or staff in the sample frame had been tested, and how testing was conducted. These limitations 
medRxiv preprint doi: https://doi.org/10.1101/2020.06.09.20125237; this version posted August 1, 2020. The copyright holder for this

preprint (which was not certified by peer review) is the author/funder, who has granted medRxiv a license to display the preprint in

It is made available under a CC-BY-NC-ND 4.0 International license .

highlight the need to establish minimum reporting standards for future studies evaluating COVID-19 related mortality and spread of disease in LTC settings.

\section{Limitations}

This living review had some limitations. First, we extracted the number of people who contracted COVID-19 as defined by study authors when there was no specific confirmatory diagnostic test mentioned in the study, which may have overestimated the number of people with confirmed COVID-19. Second, we also relied on the definitions used by study authors for deaths due to COVID-19. These sometimes relied on official mortality figures, which share the limitations of the underlying data sources. Third, we report the proportion of long-term care users who were hospitalised due to COVID-19 but this is not necessarily an indicator for severity of disease, as it is likely to partially reflect differences in policies for transferring patients to acute care hospitals. Fourth, we deviated from our protocol due to the unanticipated large volume of research identified in this area. Instead of completing all review steps in double, one reviewer was responsible for study inclusion and data extraction. However, we implemented broad eligibility criteria in order to ensure no relevant studies were missed, and all studies deemed eligible for inclusion were reviewed by the same reviewer to ensure consistency.

\section{Conclusions}

Long-term care users are particularly vulnerable during the COVID-19 pandemic, facing substantial risk of infection and death. Outbreak reports from individual long-term care facilities have shown wide variation in the spread of disease and outcomes among residents and staff. Further research into the factors determining successful prevention and containment of COVID-19 outbreaks in long-term care is needed, including for institutional and communitybased services. 
medRxiv preprint doi: https://doi.org/10.1101/2020.06.09.20125237; this version posted August 1,2020 . The copyright holder for this preprint (which was not certified by peer review) is the author/funder, who has granted medRxiv a license to display the preprint in

It is made available under a CC-BY-NC-ND 4.0 International license .

\section{References}

${ }^{1}$ COVID-19 Dashboard by the Center for Systems Science and Engineering (CSSE) at Johns Hopkins University. https://coronavirus.jhu.edu/map.html. Last accessed 23 July 2020.

${ }^{2}$ Barnett ML, Grabowski DC. Nursing Homes Are Ground Zero for COVID-19 Pandemic. JAMA Heal Forum. 2020;1(3):e200369-e200369. doi:10.1001/JAMAHEALTHFORUM.2020.0369

3 Jordan RE, Adab P, Cheng KK. Covid-19: Risk factors for severe disease and death. BMJ. 2020;368. doi:10.1136/bmj.m1198

${ }^{4}$ Onder G, Rezza G, Brusaferro S. Case-Fatality Rate and Characteristics of Patients Dying in Relation to COVID-19 in Italy. JAMA. 2020;323(18):1775-1776. doi:10.1001/jama.2020.4683

$5 \mathrm{Wu} Z$, McGoogan JM. Characteristics of and Important Lessons from the Coronavirus Disease 2019 (COVID-19) Outbreak in China: Summary of a Report of 72314 Cases from the Chinese Center for Disease Control and Prevention. JAMA. 2020;323(13):1239-1242. doi:10.1001/jama.2020.2648

${ }^{6}$ Cummings MJ, Baldwin MR, Abrams D, et al. Epidemiology, clinical course, and outcomes of critically ill adults with COVID-19 in New York City: a prospective cohort study. Lancet. 2020;395(10239):1763-1770. doi:10.1016/So140-6736(20)31189-2

7 Bhatraju PK, Ghassemieh BJ, Nichols M, et al. Covid-19 in Critically Ill Patients in the Seattle Region - Case Series. N Engl J Med. 2020;382(21):2012-2022. doi:10.1056/nejmoa2004500

${ }^{8}$ Comas-Herrera A, Zalakain J, Litwin C, et al. Mortality Associated with COVID-19 Outbreaks in Care Homes : Early International Evidence. 26 June 2020. LTCcovid.org, International LongTerm Care Policy Network, CPEC-LSE.

9 Banerjee A, Pasea L, Harris S, et al. Estimating excess 1-year mortality associated with the COVID-19 pandemic according to underlying conditions and age: a population-based cohort study. Lancet. 2020;395(10238):1715-1725. doi:10.1016/s0140-6736(20)30854-0

${ }^{10}$ McMichael TM, Currie DW, Clark S, et al. Epidemiology of Covid-19 in a Long-Term Care Facility in King County, Washington. $N$ Engl J Med. 2020;382(21):2005-2011. doi:10.1056/NEJMoa2005412

${ }^{11}$ Roxby AC, Greninger AL, Hatfield KM, et al. Detection of SARS-CoV-2 Among Residents and Staff Members of an Independent and Assisted Living Community for Older Adults - Seattle, Washington, 2020. MMWR Morb Mortal Wkly Rep. 2020;69(14):416-418. doi:10.15585/mmwr.mm6914e2

${ }^{12}$ Kimball A, Hatfield KM, Arons M, et al. Asymptomatic and Presymptomatic SARS-CoV-2 Infections in Residents of a Long-Term Care Skilled Nursing Facility - King County, Washington, March 2020. MMWR Morb Mortal Wkly Rep. 2020;69(13):377-381. doi:10.15585/mmwr.mm6913e1

${ }^{13}$ Moher D, Liberati A, Tetzlaff J, Altman DG, The PRISMA Group. Preferred Reporting Items for Systematic Reviews and Meta-Analyses: The PRISMA Statement. PLoS Med. 2009;6(6): e1000097. doi:10.1371/journal.pmedıooo97

${ }^{14}$ Ket J, Otten R, Van Dusseldorp I. Coronavirus 2019 (COVID-19) (COVID-19 SARS MERS) bmi-online search blocks. https://blocks.bmi-online.nl/catalog/397. Accessed April 17, 2020.

15 The Cochrane Collaboration. About COVID-19 Study Register: Preliminary Search Strategies for the initial phase. https://community.cochrane.org/about-covid-19-study-register. Published 2020. Accessed April 22, 2020.

${ }^{16}$ Munn Z, Moola S, Lisy K, Riitano D, Tufanaru C. Chapter 5: Systematic Reviews of Prevalence and Incidence. Joanna Briggs Institute Reviewer's Manual.; 2017. 
medRxiv preprint doi: https://doi.org/10.1101/2020.06.09.20125237; this version posted August 1, 2020. The copyright holder for this preprint (which was not certified by peer review) is the author/funder, who has granted medRxiv a license to display the preprint in

It is made available under a CC-BY-NC-ND 4.0 International license.

https://wiki.joannabriggs.org/display/MANUAL/Chapter+5\%3A+Systematic+reviews+of+prev alence+and+incidence. Accessed April 16, 2020.

${ }^{17}$ Munn Z, MClinSc SM, Lisy K, Riitano D, Tufanaru C. Methodological guidance for systematic reviews of observational epidemiological studies reporting prevalence and cumulative incidence data. Int J Evid Based Healthc. 2015;13(3):147-153. doi:10.1097/XEB.0oooooooooooo054

${ }^{18}$ Salcher-Konrad M, Jhass A, Naci H, Tan M, El-Tawil Y, Comas-Herrera A. COVID-19 related mortality and spread of disease in long-term care: first findings from a living systematic review of emerging evidence. medRxiv. 2020: doi.org/10.1101/2020.06.09.20125237.

${ }^{19}$ Abrams HR, Loomer L, Gandhi A, Grabowski DC. Characteristics of U.S. Nursing Homes with COVID-19 Cases. JAm Geriatr Soc. 2020. doi:10.1111/jgs.16661

${ }^{20}$ American Geriatrics Society. American Geriatrics Society (AGS) Policy Brief: COVID-19 and Nursing Homes. J Am Geriatr Soc. April 2020. doi:10.1111/jgs.16477

${ }^{21}$ American Geriatrics Society. American Geriatrics Society (AGS) Policy Brief: COVID-19 and Assisted Living Facilities. J Am Geriatr Soc. May 2020:jgs.16510. doi:10.1111/jgs.16510

${ }^{22}$ Arons MM, Hatfield KM, Reddy SC, et al. Presymptomatic SARS-CoV-2 Infections and Transmission in a Skilled Nursing Facility. $N$ Engl J Med. April 2020:NEJMoa2008457. doi:10.1056/NEJMoa2008457

${ }^{23}$ Baker KF, Hanrath AT, Loeff IS van der, et al. COVID-19 management in a UK NHS Foundation Trust with a High Consequence Infectious Diseases centre a detailed descriptive analysis. Medrxiv. 2020. doi:10.1101/2020.05.14.20100834

${ }^{24}$ Das A, Gopalan SS. Epidemiology of CoVID-19 and predictors of recovery in the Republic of Korea. medRxiv. 2020:2020.05.07.20094094. doi:10.1101/2020.05.07.20094094

${ }^{25}$ De Smet R, Mellaerts B, Vandewinckele H, et al. Frailty and mortality in hospitalized older adults with COVID-19: retrospective observational study. J Am Med Dir Assoc. 2020. doi:10.1016/j.jamda.2020.06.008

${ }^{26}$ Dora A V, Winnett A, Jatt LP, et al. Universal and Serial Laboratory Testing for SARS-CoV-2 at a Long-Term Care Skilled Nursing Facility for Veterans - Los Angeles, California, 2020. MMWR Morb Mortal Wkly Rep. 2020;69(21):651-655. doi:10.15585/mmwr.mm6921e1

${ }^{27}$ Fisman D, Lapointe-Shaw L, Bogoch I, McCready J, Tuite A. Failing our Most Vulnerable: COVID-19 and Long-Term Care Facilities in Ontario. medRxiv. 2020:2020.04.14.20065557. doi:10.1101/2020.04.14.20065557

${ }^{28}$ Gold JAW, Wong KK, Szablewski CM, et al. Characteristics and Clinical Outcomes of Adult Patients Hospitalized with COVID-19 - Georgia, March 2020. MMWR Morb Mortal Wkly Rep. 2020;69(18):545-550. doi:10.15585/mmwr.mm6918e1

${ }^{29}$ Grabenhorst U, Stiels-Prechtel R, Niemann M, Weckbecker K. COVID-19 in the nursing home: a case report. MMW-Fortschritte der Medizin. 2020;162(9):60-62. doi:10.1007/s15006-020-0481-o

${ }^{30}$ Graham N, Junghans C, Downes R, et al. SARS-CoV-2 infection, clinical features and outcome of COVID-19 in United Kingdom nursing homes. J Infect. 2020. doi:10.1016/j.jinf.2020.05.073

${ }^{31}$ Guery R, Delaye C, Brule N, et al. Limited effectiveness of systematic screening by nasopharyngeal RT-PCR of medicalized nursing home staff after a first case of COVID-19 in a resident. Médecine Mal Infect. May 2020. doi:10.1016/j.medmal.2020.04.020

${ }^{32}$ Kemenesi GG, Kornya LL, Toth GE, et al. Nursing homes and the elderly regarding the COVID19 pandemic: situation report from Hungary. GeroScience. May 2020:1-7. doi:10.1007/s11357-02000195-Z 
medRxiv preprint doi: https://doi.org/10.1101/2020.06.09.20125237; this version posted August 1, 2020. The copyright holder for this preprint (which was not certified by peer review) is the author/funder, who has granted medRxiv a license to display the preprint in It is made available under a CC-BY-NC-ND 4.0 International license .

33 Kim Y, Jiang X. Evolving Transmission Network Dynamics of COVID-19 Cluster Infections in South Korea: a descriptive study. medRxiv. 2020. http://medrxiv.org/lookup/doi/10.1101/2020.05.07.20091769.

${ }^{34}$ Lee SH, Son H, Peck KR. Can post-exposure prophylaxis for COVID-19 be considered as an outbreak response strategy in long-term care hospitals? Int J Antimicrob Agents. April 2020:105988. doi:10.1016/j.ijantimicag.2020.105988

${ }^{35}$ McMichael TM, Clark S, Pogosjans S, et al. COVID-19 in a long-term care facility - King county, Washington, February 27-March 9, 2020. Morb Mortal Wkly Rep. 2020;69(12):339-342. doi:10.15585/MMWR.MM6912E1

${ }^{36}$ Osterdahl M, Lee K, Ni Lochlainn M, et al. Detecting SARS-CoV-2 at Point of Care: Preliminary Data Comparing Loop-Mediated Isothermal Amplification (LAMP) to PCR. SSRN Electron J. 2020. doi:10.2139/ssrn.3564906

${ }^{37}$ Palaiodimos L, Kokkinidis DG, Li W, et al. Severe obesity is associated with higher in-hospital mortality in a cohort of patients with COVID-19 in the Bronx, New York. Metabolism. 2020:154262. doi:10.1016/j.metabol.2020.154262

${ }^{38}$ Prieto-Alhambra D, Ballo E, Coma-Redon E, et al. Hospitalization and 30-day fatality in 121,263 COVID-19 outpatient cases. medRxiv. 2020:2020.05.04.20090050. doi:10.1101/2020.05.04.20090050

39 Roxby AC, Greninger AL, Hatfield KM, et al. Outbreak Investigation of COVID-19 Among Residents and Staff of an Independent and Assisted Living Community for Older Adults in Seattle, Washington. JAMA Intern Med. May 2020. doi:10.1001/jamainternmed.2020.2233

${ }^{40}$ De Spiegeleer A, Bronselaer A, Teo JT, et al. The effects of ARBs, ACEIs and statins on clinical outcomes of COVID-19 infection among nursing home residents. J Am Med Dir Assoc. 2020. doi:10.1016/j.jamda.2020.06.018

${ }^{41}$ Stall NM, Farquharson C, Fan-Lun C, et al. A Hospital Partnership with a Nursing Home Experiencing a COVID-19 Outbreak: Description of a Multi-Phase Emergency Response in Toronto, Canada. J Am Geriatr Soc. May 2020. doi:10.1111/jgs.16625

${ }^{42}$ Stall NM, Jones A, Brown KA, Rochon PA, Costa AP. For-profit nursing homes and the risk of COVID-19 outbreaks and resident deaths in Ontario, Canada. Medrxiv. 2020. doi:10.1101/2020.05.25.20112664

${ }^{43}$ Yanover C, Mizrahi B, Kalkstein N, et al. What factors increase the risk of complications in SARS-CoV-2 positive patients? A cohort study in a nationwide Israeli health organization. medRxiv. 2020. http://medrxiv.org/lookup/doi/10.1101/2020.05.07.20091652.

${ }^{44}$ Cabrera JJ, Rey S, Perez S, et al. Pooling for SARS-CoV-2 control in care institutions. medRxiv. June 2020:2020.05·30.20108597. doi:10.1101/2020.05.30.20108597

45 Goldberg SA, Pu CT, Thompson RW, Mark E, Sequist TD, Grabowski DC. Asymptomatic Spread of COVID-19 in 97 Patients at a Skilled Nursing Facility. J Am Med Dir Assoc. 2020. doi:10.1016/j.jamda.2020.05.040

${ }^{46}$ Mills WR, Sender S, Lichtefeld J, et al. Supporting individuals with intellectual and developmental disability during the first 100 days of the COVID-19 outbreak in the USA. $J$ Intellect Disabil Res. 2020. doi:10.1111/jir.12740

47 Shea Y-F, Lam HY, Yuen JKY, et al. Maintaining zero COVID-19 infection among long term care facility residents in Hong Kong. J Am Med Dir Assoc. 2020. doi:10.1016/j.jamda.2020.05.042 
${ }^{48}$ Balestrini S, Koepp MJ, Gandhi S, et al. Clinical outcomes of SARS-CoV-2 pandemic in longterm care facilities for people with epilepsy: observational study. medRxiv. Published online June 15, 2020. doi:10.1101/2020.06.10.20123281

49 Benaque A, Gurruchaga MJ, Abdelnour C, et al. Dementia Care in Times of COVID-19: Experience at Fundació ACE in Barcelona, Spain. J Alzheimer's Dis. 2020;76(1):33-40. doi:10.3233/JAD-200547

$5^{\circ}$ Blackman C, Farber S, Feifer RA, Mor V, White EM. An Illustration of SARS-CoV-2 Dissemination Within a Skilled Nursing Facility Using Heat Maps. J Am Geriatr Soc. Published online June 13, 2020:jgs.16642. doi:10.1111/jgs.16642

${ }^{51}$ Blain H, Rolland Y, Tuaillon E, et al. Efficacy of a Test-Retest Strategy in Residents and Health Care Personnel of a Nursing Home facing a COVID-19 Outbreak. JAm Med Dir Assoc. Published online 2020. doi:10.1016/j.jamda.2020.06.013

${ }^{2}$ Borras-Bermejo B, Martinez-Gomez X, San Miguel MG, et al. Asymptomatic SARS-CoV-2 Infection in Nursing Homes, Barcelona, Spain, April 2020. Emerg Infect Dis. 2020;26(9). doi:10.3201/eid2609.202603

53 Brainard JS, Rushton S, Winters T, Hunter PR. Introduction to and spread of COVID-19 in care homes in Norfolk, UK. medRxiv. Published online June 20, 2020. doi:10.1101/2020.06.17.20133629

${ }^{54}$ Diamantis S, Noel C, Tarteret P, Vignier N, Gallien S. Severe Acute Respiratory Syndrome Coronavirus 2 (SARS-CoV-2)-Related Deaths in French Long-Term Care Facilities: The "Confinement Disease" Is Probably More Deleterious Than the Coronavirus Disease-2019 (COVID-19) Itself. J Am Med Dir Assoc. Published online 2020. doi:10.1016/j.jamda.2020.04.023

${ }^{55} \mathrm{He}$ M, Li Y, Fang F. Is there a Link between Nursing Home Reported Quality and COVID-19 Cases? Evidence from California Skilled Nursing Facilities. JAm Med Dir Assoc. Published online 2020. doi:10.1016/j.jamda.2020.06.016

${ }^{56}$ Kennelly SP, Dyer AH, Martin R, et al. Asymptomatic carriage rates and case-fatality of SARS$\mathrm{CoV}-2$ infection in residents and staff in Irish nursing homes. medRxiv. Published online June 15, 2020. doi:10.1101/2020.06.11.20128199

${ }^{57} \mathrm{Li}$ Y, Temkin-Greener H, Gao S, Cai X. COVID-19 infections and deaths among Connecticut nursing home residents: facility correlates. J Am Geriatr Soc. Published online 2020. doi:10.1111/jgs.16689

${ }^{58}$ Martín V, Fernández-Villa T, de Gomez MLG, et al. Prevalencia de la Infección por SARS-CoV2 en médicos y enfermeras de Atención Primaria y Residencias de Ancianos del Área de Salud de León y Factores asociados. Med Fam Semer. Published online 2020. doi:10.1016/j.semerg.2020.05.014

59 Martin-Jimenez P, Munoz-Garcia MI, Seoane D, et al. Cognitive impairment is a common comorbidity in COVID-19 deceased patients. A hospital-based retrospective cohort study. medRxiv. Published online June 15, 2020. doi:10.1101/2020.06.08.20125872

${ }^{60}$ Mills WR, Buccola JM, Sender S, et al. Home-Based Primary Care Led-Outbreak Mitigation in Assisted Living Facilities in the First One Hundred Days of COVID-19. J Am Med Dir Assoc. 2020;21(7):951-953. doi:10.1016/j.jamda.2020.06.014

${ }^{61}$ Mills WR, Sender S, Reynolds K, et al. An Outbreak Preparedness and Mitigation Approach in Home Health and Personal Home Care During the COVID-19 Pandemic. Home Heal Care Manag Eamp; Pract. Published online 2020. doi:10.1177/1084822320933567 
medRxiv preprint doi: https://doi.org/10.1101/2020.06.09.20125237; this version posted August 1,2020 . The copyright holder for this preprint (which was not certified by peer review) is the author/funder, who has granted medRxiv a license to display the preprint in It is made available under a perpetuity.

${ }^{62}$ Office for National Statistics. Impact of Coronavirus in Care Homes in England: 26 May to 19 June 2020.; 2020. Accessed July 2020. https://www.ons.gov.uk/peoplepopulationandcommunity/healthandsocialcare/conditionsand diseases/articles/impactofcoronavirusincarehomesinenglandvivaldi/26mayto19june2020

${ }_{63}$ Patel MC, Chaisson LH, Borgetti S, et al. Asymptomatic SARS-CoV-2 infection and COVID-19 mortality during an outbreak investigation in a skilled nursing facility. Clin Infect Dis. Published online June 2020. doi:10.1093/cid/ciaa763

${ }^{64}$ Quicke K, Gallichote E, Sexton N, et al. Longitudinal Surveillance for SARS-CoV-2 RNA Among Asymptomatic Staff in Five Colorado Skilled Nursing Facilities: Epidemiologic, Virologic and Sequence Analysis. medRxiv. Published online June 15, 2020. doi:10.1101/2020.06.08.20125989

${ }^{65}$ Raciborski F, Pinkas J, Jankowski M, et al. Dynamics of COVID-19 outbreak in Poland: an epidemiological analysis of the first two months of the epidemic. Polish Arch Intern Med. Published online 2020. doi:10.20452/pamw.15430

${ }^{66}$ Rudolph JL, Halladay CW, Barber M, et al. Temperature in Nursing Home Residents Systematically Tested for SARS-CoV-2. J Am Med Dir Assoc. Published online 2020. doi:10.1016/j.jamda.2020.06.009

${ }^{67}$ Verbeek H, Gerritsen DL, Backhaus R, De Boer BS, Koopmans RT, Hamers JP. Allowing visitors back in the nursing home during the COVID-19 crisis - A Dutch national study into first experiences and impact on well-being. J Am Med Dir Assoc. Published online 2020. doi:10.1016/j.jamda.2020.06.020

${ }^{68}$ Brown KA, Jones A, Daneman N, et al. Association Between Nursing Home Crowding and COVID-19 Infection and Mortality in Ontario, Canada. medRxiv. Published online June 26, 2020. doi:10.1101/2020.06.17.20133629

${ }^{69}$ Comas-Herrera A, Fernandez J-L, Hancock R, et al. COVID-19: Implications for the Support of People with Social Care Needs in England. J Aging Soc Policy. June 2020:1-8. doi:10.1080/08959420.2020.1759759

${ }^{70}$ Booth R. Why did so many people die of Covid-19 in the UK's care homes? The Guardian. https://www.theguardian.com/society/2020/may/28/why-did-so-many-people-die-of-covid19-in-the-uks-care-homes. Published May 28, 2020. Accessed June 8, 2020.

${ }^{71}$ NHS England and NHS Improvement. New Requirement to Test Patients Being Discharged from Hospital to a Care Home.; 2020. https://www.england.nhs.uk/coronavirus/wpcontent/uploads/sites/52/2020/04/C0324-New-requirement-to-test-patients-being-

discharged-from-hospital-to-a-care-home.pdf. Accessed June 8, 2020.

${ }^{72}$ World Health Organization. Strengthening the Health System Response to COVID-19: Preventing and Managing the COVID-19 Pandemic across Long-Term Care Services in the WHO European Region (May 29, 2020). Copenhagen; 2020. http://www.euro.who.int/_data/assets/pdf_file/ooo4/443605/Tech-guidance-6-COVID19eng.pdf?ua=1. Accessed June 8, 2020.

73 World Health Organization. Preventing and managing COVID-19 across long-term care services : policy brief. Geneva; 2020. WHO/2019-nCoV/Policy_Brief/Long-term_Care/2020.1

${ }^{74}$ Comas-Herrera A, Ashcroft EC, Lorenz-Dant K, Ashcroft EC. International Examples of Measures to Prevent and Manage COVID-19 Outbreaks in Residential Care and Nursing Home Settings. 2020. 
medRxiv preprint doi: https://doi.org/10.1101/2020.06.09.20125237; this version posted August 1, 2020. The copyright holder for this preprint (which was not certified by peer review) is the author/funder, who has granted medRxiv a license to display the preprint in It is made available under a CC-BY-NC-ND 4.0 International license .

75 Boulware DR, Pullen MF, Bangdiwala AS, et al. A Randomized Trial of Hydroxychloroquine as Postexposure Prophylaxis for Covid-19. $N$ Engl J Med. June 2020:NEJMoa2016638. doi:10.1056/NEJMoa2016638

${ }_{76}$ Sciensano. COVID-19-BULLETIN EPIDEMIOLOGIQUE DU $25 \quad$ MAI 2020.; 2020. https://epistat.wiv-isp.be/covid. Accessed June 8, 2020.

77 Williamson P, Altman D, Blazeby J, Clarke M, Gargon E. Driving up the Quality and Relevance of Research Through the Use of Agreed Core Outcomes. J Health Serv Res Policy. 2012;17(1):1-2. doi:10.1258/jhsrp.2011.011131 
medRxiv preprint doi: https://doi.org/10.1101/2020.06.09.20125237; this version posted August 1, 2020. The copyright holder for this preprint (which was not certified by peer review) is the author/funder, who has granted medRxiv a license to display the preprint in It is made available under a CC-BY-NC-ND 4.0 International license .

\section{Figures and Tables}

\section{Figure 1: Flow chart for selection of included studies}

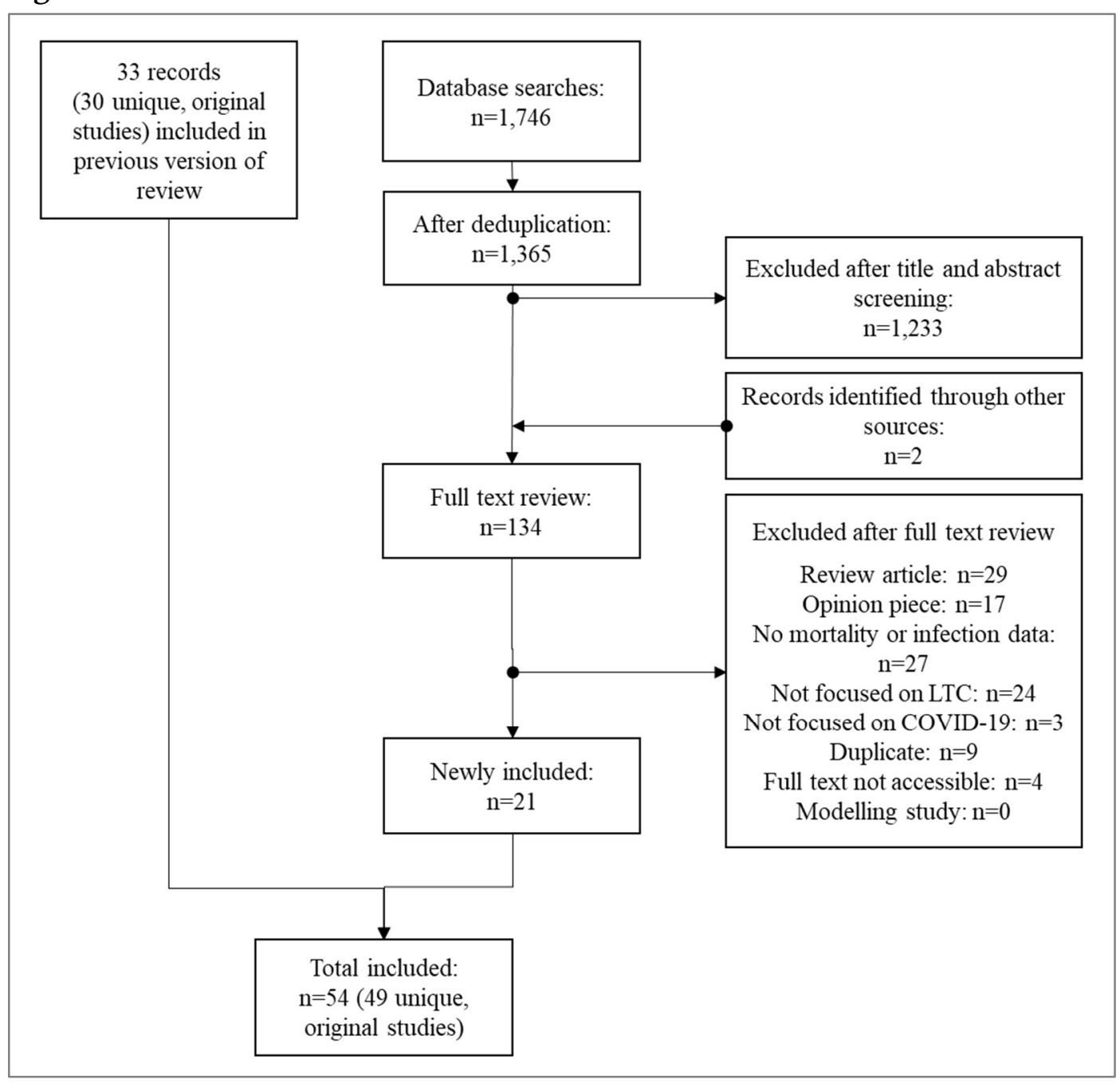


Table 1: Overview of included studies

\begin{tabular}{|c|c|c|c|c|c|}
\hline Study & Location & $\begin{array}{l}\text { Number of } \\
\text { study } \\
\text { participants }\end{array}$ & Care home type & Study overview & $\begin{array}{l}\text { Critical } \\
\text { appraisal * }\end{array}$ \\
\hline Abrams $2020^{19}$ & $\begin{array}{l}\text { United States } \\
\text { (nationwide) }\end{array}$ & $\mathrm{N} / \mathrm{A}$ & Nursing homes & $\begin{array}{l}\text { Survey of US nursing homes to identify those with at least } \\
\text { one documented COVID-19 case and association study of } \\
\text { nursing home characteristics with outbreaks. }\end{array}$ & $\begin{array}{c}\text { Not } \\
\text { applicable }\end{array}$ \\
\hline AGS ALF $2020^{20}$ & $\begin{array}{l}\text { United States } \\
\text { (Colorado) }\end{array}$ & $\begin{array}{l}46 \text { LTC users } \\
25 \text { LTC staff }\end{array}$ & $\begin{array}{l}\text { Assisted living } \\
\text { facility }\end{array}$ & $\begin{array}{l}\text { Recommendations by American Geriatrics Society, } \\
\text { containing a brief report on number of cases in an assisted } \\
\text { living facility in Colorado, US. }\end{array}$ & $\begin{array}{l}\square \square \square \square \square \\
\square \square \square \square\end{array}$ \\
\hline AGS NH $2020^{21}$ & $\begin{array}{l}\text { United States } \\
\text { (Massachusetts) }\end{array}$ & 98 LTC users & $\begin{array}{l}\text { Nursing home (no } \\
\text { further details) }\end{array}$ & $\begin{array}{l}\text { Recommendations by American Geriatrics Society, } \\
\text { containing a brief report on number of cases in a nursing } \\
\text { home in Massachusetts, US. }\end{array}$ & $\begin{array}{l}\square \square \square \square \square \\
\square \square \square \square\end{array}$ \\
\hline $\begin{array}{l}\text { Arons } 202 \mathrm{O}^{22} \& \\
\text { Kimball } 202 \mathrm{O}^{12}\end{array}$ & $\begin{array}{l}\text { United States } \\
\text { (King County, } \\
\text { Washington) }\end{array}$ & $\begin{array}{l}76 \text { LTC users } \\
138 \text { LTC staff }\end{array}$ & $\begin{array}{l}\text { Skilled nursing } \\
\text { facility }\end{array}$ & $\begin{array}{l}\text { Report by the US CDC and local public health body on an } \\
\text { outbreak investigation in a skilled nursing facility in King } \\
\text { County, Washington, US. Systematic testing and symptom } \\
\text { assessment, including two point-prevalence studies and } \\
\text { post-mortem assessment, were conducted. }\end{array}$ & $\begin{array}{l}\nabla \nabla \nabla \nabla \nabla \\
\nabla \nabla \boldsymbol{\square}\end{array}$ \\
\hline Baker $\mathbf{2 0 2 \mathrm { O } ^ { 2 3 }}$ & $\begin{array}{l}\text { United } \\
\text { Kingdom } \\
\text { (Newcastle) }\end{array}$ & 6o LTC users & $\begin{array}{l}\text { Nursing and } \\
\text { residential homes }\end{array}$ & $\begin{array}{l}\text { Pre-print of a cohort study of } 316 \text { consecutive adult } \\
\text { patients with SARS-CoV-2 PCR-confirmed COVID-19 } \\
\text { admitted to a hospital in Newcastle, England, from } 8 \\
\text { January to } 16 \text { April 2020, including } 6 \text { o from nursing and } \\
\text { residential homes. }\end{array}$ & $\begin{array}{l}\nabla \nabla \nabla \nabla \square \\
\nabla \square \square \square\end{array}$ \\
\hline Balestrini $2020^{48}$ & $\begin{array}{l}\text { United } \\
\text { Kingdom } \\
\text { (London) }\end{array}$ & $\begin{array}{l}98 \text { LTC users } \\
275 \text { LTC staff }\end{array}$ & $\begin{array}{l}\text { Long-term care } \\
\text { facility }\end{array}$ & $\begin{array}{l}\text { Pre-print of a retrospective cohort study of residents and } \\
\text { carers in } 3 \text { long-term care facilities in the London (UK) } \\
\text { area, aiming to assess the effectiveness of enhanced } \\
\text { surveillance and early prevention, and comparing } \\
\text { outcomes in residents with vs. without epilepsy. } \\
\text { Systematic testing was only conducted in one of the sites } \\
\text { (starting from } 17 \text { April for residents and from } 30 \text { April for } \\
\text { carers), and results were extracted for this facility only. }\end{array}$ & $\begin{array}{l}\nabla \nabla \nabla \square \square \\
\nabla \nabla \square \mathbf{a}^{\dagger}\end{array}$ \\
\hline Benaque $2020^{49}$ & $\begin{array}{l}\text { Spain } \\
\text { (Barcelona) }\end{array}$ & $\begin{array}{l}190 \text { LTC users } \\
\text { in day care }\end{array}$ & $\begin{array}{l}\text { Community (day } \\
\text { care centre and }\end{array}$ & $\begin{array}{l}\text { Report of the experience of an organisation providing } \\
\text { services to people with cognitive impairment in Barcelona, }\end{array}$ & 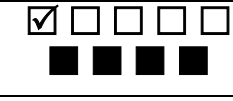 \\
\hline
\end{tabular}




\begin{tabular}{|c|c|c|c|c|c|}
\hline & & $\begin{array}{l}\text { centre; unclear } \\
\text { how many in } \\
\text { memory unit }\end{array}$ & $\begin{array}{l}\text { assessment centre } \\
\text { for diagnosis) }\end{array}$ & $\begin{array}{l}\text { Spain, including a day care unit and memory unit (referral } \\
\text { centre for diagnosis and follow-up). Describes actions } \\
\text { taken to adapt model of care to telemedicine consultation } \\
\text { for people with cognitive disorders and their families. }\end{array}$ & \\
\hline Bhatraju $2020^{7}$ & $\begin{array}{l}\text { United States } \\
\text { (Seattle, } \\
\text { Washington) }\end{array}$ & 6 LTC users & $\begin{array}{l}\text { Skilled nursing } \\
\text { facilities }\end{array}$ & $\begin{array}{l}\text { Case series of all confirmed COVID-19 patients admitted } \\
\text { to the ICU of nine hospitals in the Seattle area, from } 24 \\
\text { February to } 9 \text { March, including } 6 / 24 \text { patients who were } \\
\text { admitted from skilled nursing facilities. Patients were } \\
\text { followed up for at least } 14 \text { days. }\end{array}$ & $\begin{array}{c}\nabla \nabla \square \nabla \square \\
\nabla \nabla \mathbf{\square}\end{array}$ \\
\hline Blackman $2020^{50}$ & $\begin{array}{l}\text { United States } \\
\text { (not specified) }\end{array}$ & 150 LTC users & $\begin{array}{l}\text { Skilled nursing } \\
\text { facility }\end{array}$ & Case report of an outbreak at a skilled nursing facility. & $\begin{array}{c}\nabla \square \square \square \square \\
\square \square \mathbf{\square}\end{array}$ \\
\hline Blain $2020^{5^{1}}$ & $\begin{array}{l}\text { France } \\
\text { (Occitanie) }\end{array}$ & $\begin{array}{l}79 \text { LTC users } \\
34 \text { LTC staff }\end{array}$ & Nursing home & $\begin{array}{l}\text { Cohort study of all residents and health care personnel at } \\
\text { a nursing home who underwent weekly testing after a } \\
\text { resident was diagnosed with COVID (American Testing } \\
\text { Guidance for Nursing Homes). }\end{array}$ & $\begin{array}{c}\nabla \nabla \square \square \square \\
\nabla \square \square \boldsymbol{\square}^{\dagger}\end{array}$ \\
\hline $\begin{array}{l}\text { Borras-Bermejo } \\
2020^{52}\end{array}$ & $\begin{array}{l}\text { Spain } \\
\text { (Barcelona) }\end{array}$ & $\begin{array}{l}\text { 3,214 LTC } \\
\text { users } \\
\text { 2,655 LTC staff }\end{array}$ & Nursing homes & $\begin{array}{l}\text { Research letter reporting results of test-based screening as } \\
\text { a containment measure across residents and staff of } 69 \\
\text { nursing homes. Previous laboratory-confirmed cases of } \\
\text { COVID-19 were excluded. }\end{array}$ & $\begin{array}{c}\square \square \square \square \square \\
\square \square \square \square\end{array}$ \\
\hline Brainard $2020^{53}$ & $\begin{array}{l}\text { United } \\
\text { Kingdom } \\
\text { (Norfolk) }\end{array}$ & $\mathrm{N} / \mathrm{A}$ & $\begin{array}{l}\text { Residential care } \\
\text { homes }\end{array}$ & $\begin{array}{l}\text { Pre-print of a secondary analysis of COVID-19 infection } \\
\text { data in } 248 \text { residential care homes in Norfolk county (UK). } \\
\text { Analysis at the care home level aimed to identify } \\
\text { predictors of spread of infection. }\end{array}$ & $\begin{array}{c}\text { Not } \\
\text { applicable }\end{array}$ \\
\hline $\begin{array}{l}\text { Brown } 2020^{68} \\
\text { and Stall } 2020 a^{42} \\
\text { (two reports on } \\
\text { the same study; } \\
\text { two additional } \\
\text { studies have } \\
\text { overlapping } \\
\text { data, including a } \\
\text { case report }{ }^{41} \text { and }\end{array}$ & $\begin{array}{l}\text { Canada } \\
\text { (Ontario) }\end{array}$ & 78,607 & Nursing homes & $\begin{array}{l}\text { Pre-print of a population-based retrospective cohort study } \\
\text { of all nursing home residents in Ontario, Canada. } \\
\text { Incidence of COVID-19 during a 2-month period was } \\
\text { analysed with respect to crowding of nursing homes. }\end{array}$ & $\begin{array}{c}\nabla \square \square \square \square \\
\square \square \square \square\end{array}$ \\
\hline
\end{tabular}




\begin{tabular}{|c|c|c|c|c|c|}
\hline $\begin{array}{l}\text { a province wide } \\
\text { study with } \\
\text { shorter follow- } \\
\text { up }^{27} \text { ) }\end{array}$ & & & & & \\
\hline Cabrera $2020^{44}$ & Spain (Galicia) & $\begin{array}{l}\text { 16,477 LTC } \\
\text { users } \\
8,599 \text { LTC } \\
\text { staff } \\
\text { 310 not } \\
\text { specified }\end{array}$ & $\begin{array}{l}\text { Care homes (no } \\
\text { further details) }\end{array}$ & $\begin{array}{l}\text { Pre-print of a prevalence study of SARS-CoV-2 in all } \\
\text { nursing homes in Galicia, Spain, combined with pilot } \\
\text { testing of pooled testing strategy. }\end{array}$ & $\begin{array}{l}\nabla \nabla \nabla \square \square \\
\nabla \square \square \square\end{array}$ \\
\hline Das $2020^{24}$ & $\begin{array}{l}\text { South Korea } \\
\text { (nationwide) }\end{array}$ & N/A & $\begin{array}{l}\text { Nursing homes (no } \\
\text { further details) }\end{array}$ & $\begin{array}{l}\text { Pre-print of a cohort study of all confirmed COVID-19 } \\
\text { cases in South Korea from } 20 \text { January to } 30 \text { April 2020, } \\
\text { including } 46 \text { cases who were exposed at nursing homes. } \\
\text { No information was available about whether these cases } \\
\text { were residents or staff. }\end{array}$ & $\begin{array}{c}\text { Not } \\
\text { applicable }\end{array}$ \\
\hline De Smet $\mathbf{2 0 2 0}$ & $\begin{array}{l}\text { Belgium } \\
\text { (Bornheiden) }\end{array}$ & 42 LTC users & $\begin{array}{l}\text { Long-term care } \\
\text { residents (no } \\
\text { further details) }\end{array}$ & $\begin{array}{l}\text { Cohort study of hospitalised COVID-19 patients at the } \\
\text { geriatrics department of a Belgian hospital. }\end{array}$ & $\begin{array}{l}\nabla \nabla \nabla \square \square \\
\nabla \square \square \square\end{array}$ \\
\hline $\begin{array}{l}\text { De Spiegeleer } \\
2020^{40}\end{array}$ & $\begin{array}{l}\text { Belgium (not } \\
\text { specified) }\end{array}$ & 154 LTC users & $\begin{array}{l}\text { Nursing homes (no } \\
\text { further details) }\end{array}$ & $\begin{array}{l}\text { Retrospective cohort study of the association of the use of } \\
\text { different drugs and COVID-19 outcomes among residents } \\
\text { of } 2 \text { Belgian nursing homes. }\end{array}$ & $\begin{array}{l}\nabla \nabla \nabla \square \square \\
\nabla \nabla \square \square\end{array}$ \\
\hline $\begin{array}{l}\text { Diamantis } \\
2020^{54}\end{array}$ & $\begin{array}{l}\text { France (Ile-de- } \\
\text { France) }\end{array}$ & 140 LTC users & $\begin{array}{l}\text { Long-term care } \\
\text { facility }\end{array}$ & $\begin{array}{l}\text { Brief report in a letter about an intervention after an } \\
\text { outbreak at a French long-term care facility. }\end{array}$ & $\begin{array}{l}\nabla \square \square \square \square \\
\square \square \square \square \\
\end{array}$ \\
\hline Dora $2020^{26}$ & $\begin{array}{l}\text { United States } \\
\text { (Los Angeles) }\end{array}$ & $\begin{array}{l}\text { 99 LTC users } \\
136 \text { LTC staff }\end{array}$ & $\begin{array}{l}\text { Skilled nursing } \\
\text { facility }\end{array}$ & $\begin{array}{l}\text { Outbreak investigation at a skilled nursing facility in Los } \\
\text { Angeles, US, with serial (approximately weekly) testing of } \\
\text { all residents, and testing of all staff. }\end{array}$ & $\begin{array}{l}\nabla \nabla \square \square \square \\
\nabla \square \square \square\end{array}$ \\
\hline $\begin{array}{l}\text { Fisman } 202 \mathrm{O}^{27} \\
\text { (overlapping } \\
\text { data with Brown } \\
2020^{68} \text {, which } \\
\text { has longer } \\
\text { follow-up) }\end{array}$ & $\begin{array}{l}\text { Canada } \\
\text { (Ontario) }\end{array}$ & $\begin{array}{l}79,498 \text { LTC } \\
\text { users }\end{array}$ & $\begin{array}{l}\text { Long-term care } \\
\text { facilities (no further } \\
\text { details) }\end{array}$ & $\begin{array}{l}\text { Pre-print of a cross-sectional study analysing an outbreak } \\
\text { database created by Ontario Ministry of Health and LTC. } \\
\text { Number of long-term care beds was assumed to represent } \\
\text { all LTC users in Ontario. }\end{array}$ & $\begin{array}{l}\nabla \nabla \square \square \square \\
\square \square \square \square\end{array}$ \\
\hline
\end{tabular}




\begin{tabular}{|c|c|c|c|c|c|}
\hline Gold $2020^{28}$ & $\begin{array}{l}\text { United States } \\
\text { (Georgia) }\end{array}$ & 20 LTC users & Not specified & $\begin{array}{l}\text { Cohort study of all COVID-19 positive patients admitted } \\
\text { to hospitals in Atlanta and southern Georgia, including } 20 \\
\text { from long-term care settings. }\end{array}$ & $\begin{array}{l}\nabla \nabla \nabla \nabla \nabla \\
\nabla \nabla \square \square\end{array}$ \\
\hline Goldberg $2020^{45}$ & $\begin{array}{l}\text { United States } \\
\text { (Boston) }\end{array}$ & 97 LTC users & $\begin{array}{l}\text { Skilled nursing } \\
\text { facility }\end{array}$ & $\begin{array}{l}\text { Point-prevalence study of SARS-CoV-2 among residents } \\
\text { and staff of a skilled nursing facility. Only results for } \\
\text { residents are reported. }\end{array}$ & $\begin{array}{c}\nabla \nabla \square \square \square \\
\square \square \square \square\end{array}$ \\
\hline $\begin{array}{l}\text { Grabenhorst } \\
202 \mathrm{O}^{29} \\
\text { (including } \\
\text { follow-up data } \\
\text { obtained from } \\
\text { author) }\end{array}$ & $\begin{array}{l}\text { Germany } \\
\text { (North Rhine- } \\
\text { Westphalia) }\end{array}$ & $\begin{array}{l}122 \text { LTC users } \\
122 \text { LTC staff }\end{array}$ & Nursing home & $\begin{array}{l}\text { Case report of an outbreak and response at a nursing } \\
\text { home in Germany. All residents and staff were tested. }\end{array}$ & $\begin{array}{l}\nabla \nabla \nabla \nabla \nabla \\
\nabla \nabla \mathbf{0}\end{array}$ \\
\hline Graham $2020^{30}$ & $\begin{array}{l}\text { United } \\
\text { Kingdom } \\
\text { (London) }\end{array}$ & $\begin{array}{l}\text { 313 LTC users } \\
73 \text { LTC staff }\end{array}$ & Nursing homes & $\begin{array}{l}\text { Outbreak investigation at } 4 \text { care homes in London, UK. } \\
\text { Two point-prevalence surveys ( } 7 \text { days apart), } \\
\text { documentation of symptoms, and review of death } \\
\text { certificates were conducted. All residents were tested, and } \\
\text { a representative sample of asymptomatic staff. }\end{array}$ & $\begin{array}{l}\nabla \nabla \nabla \nabla \nabla \\
\nabla \nabla \square \square^{\dagger}\end{array}$ \\
\hline Guery $2020^{31}$ & France (Nantes) & 136 LTC staff & Nursing home & $\begin{array}{l}\text { Research letter describing a cross-sectional study of an } \\
\text { outbreak in a French nursing home, including systematic } \\
\text { testing of all staff members. }\end{array}$ & $\begin{array}{l}\nabla \nabla \nabla \nabla \nabla \\
\square \square \square \square\end{array}$ \\
\hline He $2020^{55}$ & $\begin{array}{l}\text { United States } \\
\text { (California) }\end{array}$ & $\mathrm{N} / \mathrm{A}$ & $\begin{array}{l}\text { Skilled nursing } \\
\text { facilities }\end{array}$ & $\begin{array}{l}\text { Cross-sectional study of the association between quality of } \\
1,223 \text { California nursing homes and incidence of COVID-19 } \\
\text { and death. }\end{array}$ & $\begin{array}{c}\text { Not } \\
\text { applicable }\end{array}$ \\
\hline Kemenesi $2020^{32}$ & $\begin{array}{l}\text { Hungary } \\
\text { (nationwide) }\end{array}$ & 198 LTC users & $\begin{array}{l}\text { Nursing homes (no } \\
\text { further details) }\end{array}$ & $\begin{array}{l}\text { Viral genomic analysis of COVID-19 cases that were } \\
\text { centrally recorded. No specific analysis was done for LTC } \\
\text { residents, except for reporting the proportion of cases } \\
\text { from social homes (all from nursing homes). Network } \\
\text { analysis of each case was performed. }\end{array}$ & $\begin{array}{l}\nabla \nabla \nabla \nabla \square \\
\square \square \square \square\end{array}$ \\
\hline Kennelly $2020^{56}$ & $\begin{array}{l}\text { Ireland } \\
\text { (Dublin/Eastern } \\
\text { Ireland) }\end{array}$ & $\begin{array}{l}\text { 2,043 LTC } \\
\text { users } \\
675 \text { LTC staff }\end{array}$ & Nursing homes & $\begin{array}{l}\text { Pre-print of a survey of Irish nursing homes reporting } \\
\text { outbreaks, timing of infections, case numbers and deaths. }\end{array}$ & $\begin{array}{l}\nabla \nabla \nabla \nabla \nabla \\
\square \square \square \square\end{array}$ \\
\hline $\begin{array}{l}\text { Kim \& Jiang } \\
2020^{33}\end{array}$ & $\begin{array}{l}\text { South Korea } \\
\text { (nationwide) }\end{array}$ & N/A & $\begin{array}{l}2 \text { nursing homes, } 1 \\
\text { psychiatric hospital }\end{array}$ & $\begin{array}{l}\text { Pre-print of a network study using contact tracing data } \\
\text { from the South Korean Center for Disease Controls and }\end{array}$ & $\begin{array}{c}\text { Not } \\
\text { applicable }\end{array}$ \\
\hline
\end{tabular}




\begin{tabular}{|c|c|c|c|c|c|}
\hline & & & & $\begin{array}{l}\text { Prevention to identify and describe clusters, including } 3 \\
\text { clusters in LTC settings. }\end{array}$ & \\
\hline Lee $2020^{34}$ & $\begin{array}{l}\text { South Korea } \\
\text { (Busan) }\end{array}$ & $\begin{array}{l}193 \text { LTC users } \\
123 \text { LTC staff }\end{array}$ & $\begin{array}{l}\text { Long-term care } \\
\text { hospital }\end{array}$ & $\begin{array}{l}\text { Cohort study of residents and staff of a long-term care } \\
\text { hospital. After a care worker was diagnosed, residents and } \\
\text { staff were tested and received post-exposure } \\
\text { hydroxychloroquine prophylaxis. }\end{array}$ & $\begin{array}{c}\nabla \nabla \square \square \square \\
\square \nabla \mathbf{\square}\end{array}$ \\
\hline $\mathrm{Li} 2020^{57}$ & $\begin{array}{l}\text { United States } \\
\text { (Connecticut) }\end{array}$ & $\mathrm{N} / \mathrm{A}$ & Nursing homes & $\begin{array}{l}\text { Cross-sectional analysis of } 215 \text { nursing homes in } \\
\text { Connecticut (US), aiming to assess association between } \\
\text { nursing home characteristics and COVID-19 outbreaks } \\
\text { and deaths. }\end{array}$ & $\begin{array}{c}\text { Not } \\
\text { applicable }\end{array}$ \\
\hline Martin $2020^{5^{8}}$ & Spain (Leon) & 74 LTC staff & Nursing homes & $\begin{array}{l}\text { Cross-sectional study of the prevalence of COVID-19 } \\
\text { among health workers (GPs and nurses) in } 30 \text { primary } \\
\text { care centres and } 30 \text { nursing homes in the region of Leon, } \\
\text { Spain. }\end{array}$ & $\begin{array}{l}\nabla \nabla \square \square \square \\
\square \square \square \square\end{array}$ \\
\hline $\begin{array}{l}\text { Martin-Jimenez } \\
2020^{59}\end{array}$ & Spain (Madrid) & 32 LTC users & Nursing homes & $\begin{array}{l}\text { Pre-print of a retrospective cohort study of all patients at a } \\
\text { hospital in Madrid (Spain) who died after admission. } \\
\text { Characteristics of patients included residence. }\end{array}$ & $\begin{array}{c}\square \nabla \square \square \square \\
\square \square \mathbf{a}\end{array}$ \\
\hline $\begin{array}{l}\text { McMichael } 2020 \\
\text { (two reports for } \\
\text { the same } \\
\text { outbreak) }\end{array}$ & $\begin{array}{l}\text { United States } \\
\text { (King County, } \\
\text { Washington) }\end{array}$ & $\begin{array}{l}\text { 101 LTC users } \\
\text { 50 LTC staff }\end{array}$ & $\begin{array}{l}\text { Skilled nursing } \\
\text { facility }\end{array}$ & $\begin{array}{l}\text { Report by the CDC and local public health body on an } \\
\text { outbreak investigation in a skilled nursing facility. After a } \\
\text { resident of the facility (at that point already hospitalised) } \\
\text { was diagnosed with COVID-19, a response was launched } \\
\text { to identify additional cases linked to the outbreak at this } \\
\text { facility. }\end{array}$ & $\begin{array}{c}\nabla \nabla \nabla \nabla \square \\
\nabla \square \mathbf{0}\end{array}$ \\
\hline Mills $2020 \mathrm{a}^{46}$ & $\begin{array}{l}\text { United States } \\
\text { (nationwide) }\end{array}$ & $\begin{array}{l}\text { 11,540 LTC } \\
\text { users }\end{array}$ & $\begin{array}{l}\text { Community (64\%; } \\
\text { including living } \\
\text { with family, in } \\
\text { foster care, or in a } \\
\text { small group home) } \\
\text { and institutional } \\
\text { care ( } 36 \% ; \\
\text { intermediate care } \\
\text { facilities) }\end{array}$ & $\begin{array}{l}\text { Cohort study of 11,540 people with intellectual and } \\
\text { developmental disability supported by an organisation } \\
\text { throughout the US. Symptomatic people were tested. }\end{array}$ & $\begin{array}{l}\nabla \nabla \nabla \square \square \\
\square \square \square\end{array}$ \\
\hline
\end{tabular}




\begin{tabular}{|c|c|c|c|c|c|}
\hline Mills $2020 b^{61}$ & $\begin{array}{l}\text { United States } \\
\text { (nationwide) }\end{array}$ & 47 LTC users & $\begin{array}{l}\text { Community (home } \\
\text { health and personal } \\
\text { care services) }\end{array}$ & $\begin{array}{l}\text { Report of the experience of an organisation providing } \\
\text { home health and personal care throughout the US during } \\
\text { the first } 100 \text { days of the pandemic. Outcomes data were } \\
\text { only available for cases who were detected while living in } \\
\text { the community. }\end{array}$ & $\begin{array}{c}\nabla \nabla \square \square \square \\
\square \square \square \square\end{array}$ \\
\hline Mills $2020 c^{60}$ & $\begin{array}{l}\text { United States } \\
\text { (Ohio) }\end{array}$ & $\begin{array}{l}\text { 1,794 LTC } \\
\text { users }\end{array}$ & $\begin{array}{l}\text { Assisted living } \\
\text { facilities }\end{array}$ & $\begin{array}{l}\text { Report of the experience of an organisation providing } \\
\text { visiting medical care to } 101 \text { assisted living facilities in } \\
\text { Ohio, US, during the first } 100 \text { days of the pandemic. }\end{array}$ & 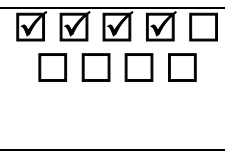 \\
\hline ONS $2020^{62}$ & $\begin{array}{l}\text { United } \\
\text { Kingdom } \\
\text { (England) }\end{array}$ & $\begin{array}{l}\text { 293,301 LTC } \\
\text { users } \\
\text { 441,498 LTC } \\
\text { staff }\end{array}$ & $\begin{array}{l}\text { Care homes for } \\
\text { people living with } \\
\text { dementia and those } \\
\text { aged } 65 \text { years and } \\
\text { over }\end{array}$ & $\begin{array}{l}\text { Report by the Office for National Statistics in England } \\
\text { (UK) on the impact of Covid-19 on care homes. Results } \\
\text { come from the Vivaldi study, a survey among 9,081 care } \\
\text { homes in England for people living with dementia and } \\
\text { those aged over } 65 \text { years }(5,126 \text { of which responded), in } \\
\text { which care home managers were asked about the number } \\
\text { of confirmed cases among residents and staff prior to } \\
\text { commencement of a comprehensive testing programme. } \\
\text { Results were weighted to account for care homes that did } \\
\text { not respond. }\end{array}$ & $\begin{array}{c}\nabla \square \square \square \square \\
\square \square \square \square\end{array}$ \\
\hline Osterdahl $2020^{36}$ & $\begin{array}{l}\text { United } \\
\text { Kingdom (no } \\
\text { further details) }\end{array}$ & 21 LTC users & $\begin{array}{l}\text { High dependency } \\
\text { care home } \\
\text { (Category } 1 \\
\text { Continuing Care) }\end{array}$ & $\begin{array}{l}\text { Pre-print of a report on an outbreak investigation at a care } \\
\text { home, including systematic testing of residents. The study } \\
\text { authors conducted testing using RT-PCR as well as RT- } \\
\text { LAMP to test whether the latter was a reliable and faster } \\
\text { alternative to RT-PCR. }\end{array}$ & $\begin{array}{c}\square \square \square \square \square \\
\square \square \square \square\end{array}$ \\
\hline $\begin{array}{l}\text { Palaiodimos } \\
2020^{37}\end{array}$ & $\begin{array}{l}\text { United States } \\
\text { (Bronx, New } \\
\text { York) }\end{array}$ & 47 LTC users & $\begin{array}{l}\text { Skilled nursing } \\
\text { facilities }\end{array}$ & $\begin{array}{l}\text { Retrospective cohort study of the first } 200 \text { laboratory } \\
\text { confirmed COVID-19 cases admitted to a teaching } \\
\text { hospital, including } 47 \text { patients from skilled nursing } \\
\text { facilities. Patients were followed up for } 3 \text { weeks after } \\
\text { hospital admission. }\end{array}$ & $\begin{array}{c}\square \square \square \square \\
\square \square \square \square\end{array}$ \\
\hline Patel $2020^{63}$ & $\begin{array}{l}\text { United States } \\
\text { (Illinois) }\end{array}$ & 126 LTC users & $\begin{array}{l}\text { Skilled nursing } \\
\text { facility }\end{array}$ & $\begin{array}{l}\text { Outbreak report from a skilled nursing facility in Illinois } \\
\text { (US), includes results from point prevalence testing of } 126 \\
\text { residents. }\end{array}$ & $\begin{array}{c}\nabla \square \square \square \square \\
\square \square \square \square^{\dagger}\end{array}$ \\
\hline $\begin{array}{l}\text { Prieto-Alhambra } \\
2020^{38}\end{array}$ & $\begin{array}{l}\text { Spain } \\
\text { (Catalonia) }\end{array}$ & $\begin{array}{l}\text { 10,795 LTC } \\
\text { users }\end{array}$ & $\begin{array}{l}\text { Nursing homes (no } \\
\text { further details) }\end{array}$ & $\begin{array}{l}\text { Pre-print of a cohort study of individuals with a positive } \\
\text { PCR test and/or a clinical diagnosis for COVID-19 in }\end{array}$ & $\begin{array}{l}\nabla \square \square \square \square \\
\square \square \square \square\end{array}$ \\
\hline
\end{tabular}




\begin{tabular}{|c|c|c|c|c|c|}
\hline & & & & $\begin{array}{l}\text { primary care records in Catalonia, Spain. Data came from } \\
\text { a primary care database covering over } 80 \% \text { of the region's } \\
\text { population (representative, according to authors), which } \\
\text { was linked to regional hospital and outpatient emergency } \\
\text { registries, central database for PCR COVID-19 tests, and } \\
\text { the regional mortality registry. }\end{array}$ & \\
\hline Quicke $2020^{64}$ & $\begin{array}{l}\text { United States } \\
\text { (Colorado) }\end{array}$ & 454 LTC staff & $\begin{array}{l}\text { Skilled nursing } \\
\text { facilities }\end{array}$ & $\begin{array}{l}\text { Pre-print of a cohort study of staff members at } 5 \text { skilled } \\
\text { nursing facilities in Colorado (US) undergoing weekly } \\
\text { testing for } 5 \text { to } 6 \text { weeks. }\end{array}$ & $\begin{array}{l}\square \square \square \square \square \\
\square \square \square \square\end{array}$ \\
\hline $\begin{array}{l}\text { Raciborski } \\
2020^{65}\end{array}$ & $\begin{array}{l}\text { Poland } \\
\text { (nationwide) }\end{array}$ & $\mathrm{N} / \mathrm{A}$ & Nursing homes & $\begin{array}{l}\text { Retrospective analysis of sociodemographic characteristics } \\
\text { of COVID-19 cases in Poland, from } 4 \text { March to } 30 \text { April } \\
2020 \text { (including place of residence, which can be a nursing } \\
\text { home). }\end{array}$ & $\begin{array}{l}\text { Not } \\
\text { applicable }\end{array}$ \\
\hline $\begin{array}{l}\text { Roxby } 2020^{11,39} \\
\text { (two reports for } \\
\text { the same } \\
\text { outbreak) }\end{array}$ & $\begin{array}{l}\text { United States } \\
\text { (King County, } \\
\text { Washington) }\end{array}$ & $\begin{array}{l}\text { 8o LTC users } \\
62 \text { LTC staff }\end{array}$ & $\begin{array}{l}\text { Independent and } \\
\text { assisted living } \\
\text { facility }\end{array}$ & $\begin{array}{l}\text { Report by the US CDC and local public health body on an } \\
\text { outbreak investigation in an independent and assisted } \\
\text { living facility. Systematic testing of all residents and staff. }\end{array}$ & $\begin{array}{l}\nabla \square \square \square \square \\
\square \square \square \square+\end{array}$ \\
\hline Rudolph $2020^{66}$ & $\begin{array}{l}\text { United States } \\
\text { (nationwide) }\end{array}$ & $\begin{array}{l}7,325 \mathrm{LTC} \\
\text { users }\end{array}$ & $\begin{array}{l}\text { Community living } \\
\text { centres for } \\
\text { residents who } \\
\text { cannot live } \\
\text { independently } \\
\text { (similar to nursing } \\
\text { homes) }\end{array}$ & $\begin{array}{l}\text { Cohort study of all residents at US Veterans } \\
\text { Administration community living centres (nursing homes) } \\
\text { who took part in one-off systematic testing for COVID-19. } \\
\text { Residents had been screened daily for COVID-19 } \\
\text { symptoms, including their temperature. }\end{array}$ & $\begin{array}{c}\square \square \square \square \square \\
\square \square \square \square\end{array}$ \\
\hline Shea $2020^{47}$ & Hong Kong & $\begin{array}{l}102 \text { LTC users } \\
60 \text { LTC staff }\end{array}$ & $\begin{array}{l}\text { Long-term care } \\
\text { facilities (no further } \\
\text { details) }\end{array}$ & $\begin{array}{l}\text { Brief description of containment of a possible outbreak at } \\
2 \text { long-term care facilities in Hong Kong. }\end{array}$ & $\begin{array}{l}\square \square \square \square \square \\
\square \square \square \square+\end{array}$ \\
\hline Stall $2020 b^{41}$ & $\begin{array}{l}\text { Canada } \\
\text { (Ontario) }\end{array}$ & 126 LTC users & Nursing home & $\begin{array}{l}\text { Brief description of an outbreak in a nursing home in } \\
\text { Toronto, Canada, prior to response initiation to through } \\
\text { partnership with an acute care hospital. }\end{array}$ & $\begin{array}{c}\square \square \square \square \square \\
\square \square \square \square\end{array}$ \\
\hline Verbeek $2020^{67}$ & $\begin{array}{l}\text { The } \\
\text { Netherlands }\end{array}$ & 2,011 LTC users & Nursing homes & $\begin{array}{l}\text { Mixed methods, cross-sectional study of the experience of } \\
26 \text { Dutch nursing homes during a pilot phase to re-open } \\
\text { nursing homes to visitors. }\end{array}$ & $\begin{array}{c}\square \square \square \square \square \\
\square \square \square \square\end{array}$ \\
\hline
\end{tabular}




\begin{tabular}{|l|l|l|l|l|}
\hline Yanover $\mathbf{2 0 2 0}^{43}$ & $\begin{array}{l}\text { Israel } \\
\text { (nationwide) }\end{array}$ & 67 LTC users & $\begin{array}{l}\text { Nursing homes (no } \\
\text { further details) }\end{array}$ & $\begin{array}{l}\text { Pre-print of a cohort study of all SARS-CoV-2 positive } \\
\text { cases in an Israeli health plan representing one quarter of } \\
\text { the Israeli population, including } 67 \text { nursing home } \\
\text { residents. }\end{array}$ \\
\hline
\end{tabular}

* Tick marks indicate number of "Yes, appropriate" responses, empty boxes indicate "No, not appropriate" or "Unclear" responses, and black boxes indicate "Not applicable" responses to Joanna Briggs Institute critical appraisal tool for prevalence studies.

${ }^{\dagger}$ Critical appraisal for LTC users. 
Table 2: Incidence of confirmed COVID-19 among long-term care users and staff in potential outbreak facilities

\begin{tabular}{|c|c|c|c|c|c|c|}
\hline Study & $\begin{array}{l}\text { Incidence } \\
\text { rate }\end{array}$ & $\begin{array}{l}\text { Number of } \\
\text { people } \\
\text { who } \\
\text { contracted } \\
\text { COVID-19 }\end{array}$ & $\begin{array}{l}\text { Number of } \\
\text { users / } \\
\text { staff }\end{array}$ & $\begin{array}{l}\text { Time } \\
\text { period }\end{array}$ & Source population & Diagnosis \\
\hline \multicolumn{7}{|c|}{ Incidence of confirmed COVID-19 among long-term care users in potential outbreak facilities } \\
\hline AGS ALF 2020 (US) & $71.7 \%$ & 33 & 46 & $\begin{array}{l}\text { Not } \\
\text { reported }\end{array}$ & No details reported & $\begin{array}{l}\text { Positive test } \\
\text { (no details) }\end{array}$ \\
\hline Stall 2020 b (Canada) & $70.6 \%$ & 89 & 126 & 2 weeks & $\begin{array}{l}\text { All nursing home residents, assuming full occupancy } \\
\text { of 126-bed facility }\end{array}$ & $\begin{array}{l}\text { Infected (no } \\
\text { details) }\end{array}$ \\
\hline Arons 2020 (US) & $63.2 \%$ & 48 & 76 & 7 days & $\begin{array}{l}76 \text { out of all } 89 \text { residents at the investigated skilled } \\
\text { nursing facility }\end{array}$ & PCR \\
\hline Goldberg 2020 (US) & $53.6 \%$ & 52 & 97 & $\begin{array}{l}\text { Not } \\
\text { reported } \\
\text { (point- } \\
\text { prevalence } \\
\text { survey) }\end{array}$ & All 97 nursing home residents were tested & PCR \\
\hline AGS NH 2020 (US) & $51.0 \%$ & 50 & 98 & $\begin{array}{l}\text { Not } \\
\text { reported }\end{array}$ & $\begin{array}{l}\text { All residents at the investigated nursing home who } \\
\text { were asymptomatic }\end{array}$ & $\begin{array}{l}\text { Positive test } \\
\text { (no details) }\end{array}$ \\
\hline Blain 2020 (France) & $48.1 \%$ & 38 & 79 & 6 weeks & $\begin{array}{l}\text { All } 79 \text { residents at the nursing home participating in } \\
\text { weekly PCR testing }\end{array}$ & PCR \\
\hline Osterdahl 2020 (UK) & $47.6 \%$ & 10 & 21 & 4 days & $\begin{array}{l}21 \text { out of all } 24 \text { residents at the investigated nursing } \\
\text { home }\end{array}$ & PCR \\
\hline Graham 2020 (UK) & $40.3 \%$ & 126 & 313 & 7 days & $\begin{array}{l}\text { Appr. } 94 \% \text { of all residents at the time of systematic } \\
\text { testing (available and consented to testing) }\end{array}$ & PCR \\
\hline Patel 2020 (US) & $26.2 \%$ & 33 & 126 & $\begin{array}{l}\text { Point } \\
\text { prevalence }\end{array}$ & $\begin{array}{l}126 \text { residents at the investigated facility who } \\
\text { consented to testing ( } 1 \text { refused) }\end{array}$ & PCR \\
\hline Dora 2020 (US) & $19.2 \%$ & 19 & 99 & 26 days & All 99 residents at the facility at the time of outbreak & PCR \\
\hline $\begin{array}{l}\text { Grabenhorst } 2020 \\
\text { (Germany) }\end{array}$ & $13.1 \%$ & 16 & 122 & 69 days & All 122 residents at the time of systematic testing & PCR \\
\hline
\end{tabular}




\begin{tabular}{|c|c|c|c|c|c|c|}
\hline Balestrini 2020 (UK) & $9.2 \%$ & 9 & 98 & 12 weeks & All 98 residents at the long-term care facility & PCR \\
\hline Roxby 2020 (US) & $5.0 \%$ & 4 & 80 & 7 days & $\begin{array}{l}\text { All residents at the investigated assisted living facility } \\
\text { except for } 2 \text { index cases }\end{array}$ & PCR \\
\hline Shea 2020 (Hong Kong) & $0.0 \%$ & o & 102 & 28 days & $\begin{array}{l}\text { Most residents at } 2 \text { long-term care facilities where an } \\
\text { infected nurse worked (total number of residents at } \\
\text { the facilities is unclear) }\end{array}$ & PCR \\
\hline Lee 2020 (Korea) & $0.0 \%$ & o & 193 & 20 days & $\begin{array}{l}\text { All } 193 \text { inpatients at the investigated long-term care } \\
\text { hospital who were exposed to an infected care worker }\end{array}$ & PCR \\
\hline \multicolumn{7}{|c|}{ Incidence of confirmed COVID-19 among long-term care staff in potential outbreak facilities } \\
\hline AGS ALF 2020 (US) & $64.0 \%$ & 16 & 25 & $\begin{array}{l}\text { Not } \\
\text { reported }\end{array}$ & No details reported & $\begin{array}{l}\text { Positive test } \\
\text { (no details) }\end{array}$ \\
\hline Patel 2020 (US) & $45.2 \%$ & 19 & 42 & $\begin{array}{l}\text { Point } \\
\text { prevalence }\end{array}$ & $\begin{array}{l}42 \text { staff members were tested out of } 70 \text { who were } \\
\text { offered testing }\end{array}$ & PCR \\
\hline Blain 2020 (France) & $23.5 \%$ & 8 & 34 & 6 weeks & $\begin{array}{l}\text { All } 35 \text { health care personnel at the nursing home } \\
\text { participating in weekly PCR testing }\end{array}$ & PCR \\
\hline Quicke 2020 (US) & $19.9 \%$ & 70 & 351 & 6 weeks & $\begin{array}{l}351 \text { workers at four facilities where cases were } \\
\text { detected (systematic, weekly testing among } \\
\text { consenting individuals) }\end{array}$ & PCR \\
\hline Arons 2020 (US) & $18.8 \%$ & 26 & 138 & 24 days & $\begin{array}{l}\text { All } 138 \text { full-time staff members at the investigated } \\
\text { skilled nursing facility (51 of which were tested) }\end{array}$ & PCR \\
\hline Dora 2020 (US) & $5.9 \%$ & 26 & 138 & 13 days & $\begin{array}{l}\text { All } 138 \text { full-time staff members at the investigated } \\
\text { skilled nursing facility ( } 51 \text { of which were tested) }\end{array}$ & PCR \\
\hline Graham 2020 (UK) & $4.1 \%$ & 3 & 73 & 1-2 days & $\begin{array}{l}\text { Sample of } 11.8 \% \text { of staff members asymptomatic at the } \\
\text { time of testing (representing all staff roles including } \\
\text { health care assistants, registered nurses, kitchen staff, } \\
\text { administrators, domestic and maintenance staff) }\end{array}$ & PCR \\
\hline $\begin{array}{l}\text { Grabenhorst } 2020 \\
\text { (Germany) }\end{array}$ & $3 \cdot 3 \%$ & 4 & 122 & 69 days & $\begin{array}{l}\text { All } 122 \text { staff members at the time of systematic testing } \\
\text { (including maintenance personnel) }\end{array}$ & PCR \\
\hline Roxby 2020 (US) & $3.2 \%$ & 2 & 62 & 2 days & All staff members working at the investigated facility & PCR \\
\hline
\end{tabular}




\begin{tabular}{|l|c|c|c|l|l|l|}
\hline Guery 2020 (France) & $2.2 \%$ & 3 & 136 & 2 days & $\begin{array}{l}\text { All 136 staff members, health workers, and } \\
\text { administrative personnel at the investigated nursing } \\
\text { home }\end{array}$ & $\begin{array}{l}\text { PCR } \\
\text { All 6o staff at 2 long-term care facilities where an } \\
\text { infected nurse worked }\end{array}$ \\
\hline Shea 2020 (Hong Kong) & $1.7 \%$ & 1 & 60 & 28 days & PCR \\
\hline Lee 2020 (Korea) & $1.5 \%$ & 2 & 132 & 20 days & All 123 staff at the investigated long-term care hospital & PCR \\
\hline Balestrini 2020 (UK) & $0.4 \%$ & 1 & 275 & 12 weeks & $\begin{array}{l}\text { All 275 asymptomatic carers at the facility (systematic } \\
\text { testing was started 4 weeks after the first case was } \\
\text { detected) }\end{array}$ \\
\hline
\end{tabular}

Abbreviations: PCR, polymerase chain reaction 
Table 3: Incidence of confirmed COVID-19 among long-term care users and staff (population-wide studies)

\begin{tabular}{|c|c|c|c|c|c|c|}
\hline Study & $\begin{array}{l}\text { Incidence } \\
\text { rate }\end{array}$ & $\begin{array}{l}\text { Number of } \\
\text { people } \\
\text { who } \\
\text { contracted } \\
\text { COVID-19 }\end{array}$ & $\begin{array}{l}\text { Number of } \\
\text { users / } \\
\text { staff }\end{array}$ & Time period & Source population & Diagnosis \\
\hline \multicolumn{7}{|c|}{ Incidence of confirmed COVID-19 among long-term care users (population-wide studies) } \\
\hline $\begin{array}{l}\text { Kennelly } 2020 \text { (Dublin } \\
\text { and Eastern Ireland, } \\
\text { Ireland) }\end{array}$ & $40.8 \%$ & 710 & 1741 & 12 weeks & $\begin{array}{l}\text { All } 1741 \text { residents in nursing homes which had } \\
\text { outbreaks and responded to survey (excluding } \\
\text { nursing homes without outbreaks). }\end{array}$ & PCR \\
\hline $\begin{array}{l}\text { Borras-Bermejo 2020 } \\
\text { (Barcelona, Spain) }\end{array}$ & $23.9 \%$ & N/A & 3214 & $\begin{array}{l}\text { Point-prevalence } \\
\text { (conducted over } 2 \\
\text { weeks) }\end{array}$ & $\begin{array}{l}\text { Residents at } 69 \text { nursing homes in Barcelona } \\
\text { (Spain) who had not previously been } \\
\text { diagnosed with COVID-19. }\end{array}$ & PCR \\
\hline $\begin{array}{l}\text { ONS } 2020 \text { (England, } \\
\text { UK) }\end{array}$ & $10.7 \%$ & $\mathrm{~N} / \mathrm{A}$ & 293301 & 16 weeks & $\begin{array}{l}\text { All care home residents in 9,081 surveyed } \\
\text { homes in England (UK). No systematic testing. }\end{array}$ & $\begin{array}{l}\text { Confirmed } \\
\text { (no further } \\
\text { details) }\end{array}$ \\
\hline $\begin{array}{l}\text { Brown } 2020 \text { (Ontario, } \\
\text { Canada) }\end{array}$ & $6.6 \%$ & 5218 & 78607 & $7 \cdot 5$ weeks & $\begin{array}{l}\text { All residents in Ontario (Canada) nursing } \\
\text { homes with complete information ( } 99 \% \text { of all } \\
\text { homes). No systematic testing. }\end{array}$ & $\begin{array}{l}\text { Confirmed } \\
\text { (no further } \\
\text { details) }\end{array}$ \\
\hline Rudolph 2020 (US) & $6.0 \%$ & 443 & 7325 & Point-prevalence & $\begin{array}{l}\text { Veterans residing in VA community living } \\
\text { centres (US) who participated in universal } \\
\text { screening (excluding those who were tested } \\
\text { due to symptoms prior to universal screening; } \\
\text { those who were tested prior to admission to } \\
\text { the centres; and those who were not tested). }\end{array}$ & PCR \\
\hline $\begin{array}{l}\text { Verbeek 2020 (The } \\
\text { Netherlands) }\end{array}$ & $1.4 \%$ & 29 & 2011 & Unclear & $\begin{array}{l}\text { Residents at } 26 \text { Dutch nursing homes included } \\
\text { in the study (nationally representative for } \\
\text { regions; no systematic testing). }\end{array}$ & $\begin{array}{l}\text { Infected with } \\
\text { COVID-19 } \\
\text { (not further } \\
\text { specified) }\end{array}$ \\
\hline Mills 2020 c (Ohio, US) & $0.4 \%$ & 7 & 1794 & 14 weeks & $\begin{array}{l}\text { People in assisted living facilities in Ohio (US) } \\
\text { and receiving visiting medical care from the }\end{array}$ & PCR \\
\hline
\end{tabular}




\begin{tabular}{|c|c|c|c|c|c|c|}
\hline & & & & & $\begin{array}{l}\text { organisation behind the study (no systematic } \\
\text { testing). }\end{array}$ & \\
\hline \multicolumn{7}{|c|}{ Incidence of confirmed COVID-19 among long-term care staff (population-wide studies) } \\
\hline $\begin{array}{l}\text { Kennelly } 2020 \text { (Dublin } \\
\text { and Eastern Ireland, } \\
\text { Ireland) }\end{array}$ & $23.8 \%$ & 331 & 1392 & 12 weeks & $\begin{array}{l}\text { Staff at nursing homes who responded to } \\
\text { survey and provided staffing numbers (half of } \\
\text { all responding nursing homes). }\end{array}$ & PCR \\
\hline $\begin{array}{l}\text { Borras-Bermejo } 2020 \\
\text { (Barcelona, Spain) }\end{array}$ & $15.2 \%$ & N/A & 2,655 & $\begin{array}{l}\text { Point-prevalence } \\
\text { (conducted over } 2 \\
\text { weeks) }\end{array}$ & $\begin{array}{l}\text { Staff at } 69 \text { nursing homes in Barcelona (Spain) } \\
\text { who had not previously been diagnosed with } \\
\text { COVID-19. }\end{array}$ & PCR \\
\hline $\begin{array}{l}\text { Martin } 2020 \text { (Leon, } \\
\text { Spain) }\end{array}$ & $9 \cdot 5 \%$ & 7 & 74 & $\begin{array}{l}\text { Point-prevalence } \\
\text { study }\end{array}$ & $\begin{array}{l}\text { Health care workers (GPs and nurses) working } \\
\text { in } 30 \text { nursing homes in Leon (Spain) and who } \\
\text { agreed to participate in the study. }\end{array}$ & $\begin{array}{l}\text { Rapid } \\
\text { diagnostic } \\
\text { antibody test }\end{array}$ \\
\hline $\begin{array}{l}\text { ONS } 2020 \text { (England, } \\
\text { UK) }\end{array}$ & $4.0 \%$ & N/A & 441,498 & 16 weeks & $\begin{array}{l}\text { All care home staff in 9,081 surveyed homes in } \\
\text { England (UK), including cleaning, catering } \\
\text { and admin (no systematic testing). }\end{array}$ & $\begin{array}{l}\text { Confirmed } \\
\text { (no further } \\
\text { details) }\end{array}$ \\
\hline
\end{tabular}

Abbreviations: PCR, polymerase chain reaction 
Table 4: Proportion of asymptomatic cases at time of testing

\begin{tabular}{|c|c|c|c|c|c|}
\hline Study & $\begin{array}{l}\text { Proportion of } \\
\text { asymptomatic } \\
\text { cases at time } \\
\text { of testing }\end{array}$ & $\begin{array}{l}\text { Number of } \\
\text { asymptomatic } \\
\text { people who } \\
\text { contracted } \\
\text { COVID-19 }\end{array}$ & $\begin{array}{l}\text { Number of } \\
\text { people } \\
\text { who } \\
\text { contracted } \\
\text { COVID-19 }\end{array}$ & Symptoms reported & Source population \\
\hline \multicolumn{6}{|c|}{ Asymptomatic people among long-term care users } \\
\hline $\begin{array}{l}\text { Balestrini } 2020 \\
\text { (UK) }\end{array}$ & $78 \%$ & 7 & 9 & Fever (37.8) and/or respiratory symptoms & $\begin{array}{l}\text { All } 98 \text { residents at the long-term care } \\
\text { facility }\end{array}$ \\
\hline Roxby 2020 (US) & $75 \%$ & 3 & 4 & $\begin{array}{l}\text { Cough in past } 14 \text { days; loose bowel } \\
\text { movement. }\end{array}$ & $\begin{array}{l}\text { All residents at the investigated } \\
\text { assisted living facility except for } 2 \\
\text { index cases. }\end{array}$ \\
\hline Dora 2020 (US) & $74 \%$ & 14 & 19 & $\begin{array}{l}\text { Fever; myalgia; headache; cough; dyspnoea; } \\
\text { nausea; emesis; diarrhoea; anorexia. }\end{array}$ & $\begin{array}{l}\text { Source population are all } 99 \text { residents } \\
\text { at the facility. Asymptomatic cases } \\
\text { include presymptomatic ones. }\end{array}$ \\
\hline $\begin{array}{l}\text { Borras-Bermejo } \\
2020 \text { (Spain) }\end{array}$ & $70 \%$ & $\mathrm{~N} / \mathrm{A}$ & $\mathrm{N} / \mathrm{A}$ & $\begin{array}{l}\text { Fever or acute respiratory symptoms within } \\
\text { the past } 14 \text { days }\end{array}$ & $\begin{array}{l}\text { All residents at } 69 \text { nursing homes who } \\
\text { had not been diagnosed with COVID- } \\
19 \text { before }\end{array}$ \\
\hline Arons 2020 (US) & $56 \%$ & 27 & 48 & $\begin{array}{l}\text { Typical symptoms: fever (37.8); cough' } \\
\text { shortness of breath } \\
\text { Symptomatic atypical: chills; malaise; } \\
\text { increased confusion; rhinorrhoea; nasal } \\
\text { congestion; sore throat; myalgia; dizziness; } \\
\text { headache; nausea; diarrhoea. Time frame } \\
\text { prev. } 14 \text { days. }\end{array}$ & $\begin{array}{l}76 \text { out of all } 89 \text { residents at the } \\
\text { investigated skilled nursing facility. }\end{array}$ \\
\hline $\begin{array}{l}\text { Graham } 2020 \\
\text { (UK) }\end{array}$ & $43 \%$ & 54 & 126 & $\begin{array}{l}\text { Cough or fever in the previous } 14 \text { days; } \\
\text { confusion; altered behaviour; anorexia; } \\
\text { diarrhoea/vomiting; shortness of breath. }\end{array}$ & $\begin{array}{l}\text { Appr. } 94 \% \text { of all residents at the time } \\
\text { of systematic testing (available and } \\
\text { consented to testing). }\end{array}$ \\
\hline Patel 2020 (US) & $42 \%$ & 14 & 33 & $\begin{array}{l}\text { "Typical": fever, cough, shortness of breath, } \\
\text { hypoxia; "Atypical": sore throat, nasal } \\
\text { congestion, diarrhoea, decreased appetite, }\end{array}$ & $\begin{array}{l}126 \text { residents at the investigated } \\
\text { facility who consented to testing (1 } \\
\text { refused) }\end{array}$ \\
\hline
\end{tabular}




\begin{tabular}{|c|c|c|c|c|c|}
\hline & & & & $\begin{array}{l}\text { chills, myalgias, headaches, new-onset } \\
\text { confusion }\end{array}$ & \\
\hline $\begin{array}{l}\text { Kennelly } 2020 \\
\text { (Ireland) }\end{array}$ & $27 \%$ & 193 & 710 & $\begin{array}{l}\text { Cough; fever; dyspnoea; atypical symptoms } \\
\text { (not specified) }\end{array}$ & $\begin{array}{l}\text { All } 1741 \text { residents in Irish nursing } \\
\text { homes which had outbreaks and } \\
\text { responded to survey (excluding } \\
\text { nursing homes without outbreaks) }\end{array}$ \\
\hline $\begin{array}{l}\text { De Spiegeleer } \\
2020 \text { (Belgium) }\end{array}$ & $27 \%$ & 41 & 154 & $\begin{array}{l}\text { Cough; dyspnoea; runny nose; sore throat; } \\
\text { general weakness; headache; confusion; } \\
\text { muscle pain; arthralgia; diarrhoea; } \\
\text { abdominal pain; vomiting; fever }>37.6 \text {; } \\
\text { increased } \mathrm{O}_{2} \text { requirement or } \mathrm{O}_{2} \\
\text { saturations }<=92 \% \text {. }\end{array}$ & $\begin{array}{l}\text { All residents at the nursing home with } \\
\text { clinical COVID-19 diagnosis or } \\
\text { positive PCR test. }\end{array}$ \\
\hline $\begin{array}{l}\text { Osterdahl } 2020 \\
\text { (UK) }\end{array}$ & $20 \%$ & 2 & 10 & Fevers (>37.3); reduced oxygen saturations. & $\begin{array}{l}21 \text { out of all } 24 \text { residents at the } \\
\text { investigated nursing home. 10 COVID- } \\
19 \text { cases identified using PCR, not RT- } \\
\text { LAMP method where a further } 3 \text { were } \\
\text { identified. }\end{array}$ \\
\hline $\begin{array}{l}\text { Blain 2020 } \\
\text { (France) }\end{array}$ & $16 \%$ & 6 & 38 & $\begin{array}{l}\text { "Typical Covid } 19 \text { symptoms": temperature, } \\
\text { cough, shortness of breath, saturation rate } \\
<100 \% \text {, respiratory rate }>24 \text {; "Atypical Covid } \\
19 \text { symptoms" (not specified) }\end{array}$ & $\begin{array}{l}\text { All } 79 \text { residents at the nursing home } \\
\text { participating in weekly PCR testing }\end{array}$ \\
\hline McMichael (US) & $7 \%$ & 7 & 101 & Cough; fever; dyspnoea. & $\begin{array}{l}118 \text { out of all approximately } 130 \\
\text { residents at the investigated skilled } \\
\text { nursing facility. }\end{array}$ \\
\hline \multicolumn{6}{|c|}{ Asymptomatic people among long-term care staff } \\
\hline Roxby 2020 (US) & $100 \%$ & 2 & 2 & Body aches; cough; headache & $\begin{array}{l}\text { All staff working at the investigated } \\
\text { assisted living facility. }\end{array}$ \\
\hline $\begin{array}{l}\text { Graham } 2020 \\
\text { (UK) }\end{array}$ & $100 \%$ & 3 & 3 & Cough or fever in the previous 14 days. & $\begin{array}{l}\text { Only asymptomatic staff members } \\
\text { were tested. Sample of } 11.8 \% \text { of staff } \\
\text { members (representing all staff roles } \\
\text { including health care assistants, } \\
\text { registered nurses, kitchen staff, }\end{array}$ \\
\hline
\end{tabular}




\begin{tabular}{|l|c|c|c|l|l|}
\hline & & & & & $\begin{array}{l}\text { administrators, domestic and } \\
\text { maintenance staff). }\end{array}$ \\
\hline $\begin{array}{l}\text { Guery 2020 } \\
\text { (France) }\end{array}$ & $67 \%$ & 2 & 3 & $\begin{array}{l}\text { Asthenia; headache; myalgias; rhinitis; } \\
\text { dysosmia; altered sense of taste. }\end{array}$ & $\begin{array}{l}\text { All 136 staff members, health workers, } \\
\text { and administrative personnel at the } \\
\text { investigated nursing home. }\end{array}$ \\
\hline $\begin{array}{l}\text { Borras-Bermejo } \\
2020 \text { (Spain) }\end{array}$ & $56 \%$ & N/A & N/A & $\begin{array}{l}\text { Fever or acute respiratory symptoms within } \\
\text { the past 14 days }\end{array}$ & $\begin{array}{l}\text { All staff at 69 nursing homes who had } \\
\text { not been diagnosed with COVID-19 } \\
\text { before }\end{array}$ \\
\hline Dora 2020 (US) & $50 \%$ & 4 & 8 & $\begin{array}{l}\text { Fever, myalgia, headache, cough, dyspnoea, } \\
\text { nausea, emesis, diarrhoea, anorexia }\end{array}$ & $\begin{array}{l}\text { All 136 staff members were tested, 8 } \\
\text { tested positive. }\end{array}$ \\
\hline $\begin{array}{l}\text { Blain 2020 } \\
\text { (France) }\end{array}$ & $38 \%$ & 3 & 8 & $\begin{array}{l}\text { "Typical Covid 19 symptoms": temperature, } \\
\text { cough, shortness of breath, saturation rate } \\
<100 \% \text {, respiratory rate >24; "Atypical Covid } \\
\text { 19 symptoms" (not specified) }\end{array}$ & $\begin{array}{l}\text { All } \\
\text { nursing home participating in weekly } \\
\text { PCR testing }\end{array}$ \\
\hline $\begin{array}{l}\text { Kennelly 2020 } \\
\text { (Ireland) }\end{array}$ & $24 \%$ & 159 & 675 & $\begin{array}{l}\text { Cough; fever; dyspnoea; atypical symptoms } \\
\text { (not specified) }\end{array}$ & $\begin{array}{l}\text { Staff at Irish nursing homes } \\
\text { responding to a survey }\end{array}$ \\
\hline
\end{tabular}


medRxiv preprint doi: https://doi.org/10.1101/2020.06.09.20125237; this version posted August 1, 2020. The copyright holder for this preprint (which was not certified by peer review) is the author/funder, who has granted medRxiv a license to display the preprint in It is made available under a CC-BY-NC-ND 4.0 International license .

Table 5: Case fatality rates among long-term care users and staff 


\begin{tabular}{|c|c|c|c|c|c|}
\hline Study & CFR & $\begin{array}{l}\text { Number of } \\
\text { people } \\
\text { who } \\
\text { contracted } \\
\text { COVID-19 } \\
\end{array}$ & $\begin{array}{l}\text { Time } \\
\text { period }\end{array}$ & Source population & Diagnosis \\
\hline \multicolumn{6}{|c|}{ CFR among long-term care users } \\
\hline $\begin{array}{l}\text { McMichael } 2020 \\
\text { (US) }\end{array}$ & $33.7 \%$ & 101 & 3 weeks & $\begin{array}{l}118 \text { out of all approximately } \\
130 \text { residents at the } \\
\text { investigated skilled nursing } \\
\text { facility }\end{array}$ & $\begin{array}{l}\text { Confirmed } \\
\text { cases (not } \\
\text { further } \\
\text { specified; PCR } \\
\text { testing } \\
\text { according to } \\
\text { CDC guidelines } \\
\text { mentioned) }\end{array}$ \\
\hline $\begin{array}{l}\text { Blain } 2020 \\
\text { (France) }\end{array}$ & $31.6 \%$ & 38 & 6 weeks & $\begin{array}{l}\text { All } 79 \text { nursing home } \\
\text { residents (all were tested) }\end{array}$ & PCR \\
\hline Patel 2020 (US) & $28.6 \%$ & 35 & 4 weeks & $\begin{array}{l}8 \text { symptomatic residents } \\
\text { and } 118 \text { remaining residents } \\
\text { who consented to testing ( } 1 \\
\text { resident refused) }\end{array}$ & PCR \\
\hline Arons 2020 (US) & $26.3 \%$ & 57 & $\begin{array}{l}3 \cdot 5 \\
\text { weeks }\end{array}$ & $\begin{array}{l}76 \text { out of all } 89 \text { residents at } \\
\text { the investigated skilled } \\
\text { nursing facility }\end{array}$ & PCR \\
\hline $\begin{array}{l}\text { Osterdahl } 2020 \\
\text { (UK) }\end{array}$ & $20.0 \%$ & 10 & 1 week & $\begin{array}{l}21 \text { out of all } 21 \text { residents at } \\
\text { the investigated nursing } \\
\text { home }\end{array}$ & PCR \\
\hline $\begin{array}{l}\text { Graham } 2020 \\
\text { (UK) }\end{array}$ & $16.7 \%$ & 126 & 2 weeks & $\begin{array}{l}\text { Appr. } 94 \% \text { of all residents at } \\
\text { the time of systematic } \\
\text { testing (available and } \\
\text { consented to testing) }\end{array}$ & PCR \\
\hline $\begin{array}{l}\text { Stall } 2020 \text { b } \\
\text { (Canada) }\end{array}$ & $13.5 \%$ & 89 & 2 weeks & $\begin{array}{l}\text { All } 126 \text { residents at outbreak } \\
\text { facility, assuming full } \\
\text { occupancy. No details on } \\
\text { whether systematic testing } \\
\text { was conducted. }\end{array}$ & $\begin{array}{l}\text { Infected (not } \\
\text { further } \\
\text { specified) }\end{array}$ \\
\hline $\begin{array}{l}\text { Grabenhorst } 2020 \\
\text { (Germany) }\end{array}$ & $12.5 \%$ & 16 & $\begin{array}{l}9.5 \\
\text { weeks }\end{array}$ & $\begin{array}{l}\text { All residents at the } \\
\text { investigated nursing home }\end{array}$ & PCR \\
\hline $\begin{array}{l}\text { Balestrini } 2020 \\
\text { (UK) }\end{array}$ & $11.1 \%$ & 9 & 12 weeks & $\begin{array}{l}\text { All } 98 \text { residents at a long- } \\
\text { term care facility that } \\
\text { conducted systematic } \\
\text { testing }\end{array}$ & PCR \\
\hline Dora 2020 (US) & $5 \cdot 3 \%$ & 19 & $\begin{array}{l}3 \cdot 5 \\
\text { weeks }\end{array}$ & $\begin{array}{l}\text { All } 99 \text { residents at the } \\
\text { facility at the time of } \\
\text { outbreak }\end{array}$ & PCR \\
\hline Roxby 2020 (US) & $0.0 \%$ & 4 & 3 weeks & $\begin{array}{l}\text { All residents at the } \\
\text { investigated assisted living } \\
\text { facility except for } 2 \text { index } \\
\text { cases }\end{array}$ & PCR \\
\hline
\end{tabular}


medRxiv preprint doi: https://doi.org/10.1101/2020.06.09.20125237; this version posted August 1, 2020. The copyright holder for this preprint (which was not certified by peer review) is the author/funder, who has granted medRxiv a license to display the preprint in It is made available under a CC-BY-NC-ND 4.0 International license .

\begin{tabular}{|l|c|c|c|l|l|}
\hline $\begin{array}{l}\text { McMichael 2020 } \\
\text { (US) }\end{array}$ & $0.0 \%$ & 50 & 3 weeks & $\begin{array}{l}\text { Not reported how many of } \\
\text { approximately 170 staff at } \\
\text { the investigated skilled } \\
\text { nursing facility were tested }\end{array}$ & $\begin{array}{l}\text { Confirmed } \\
\text { cases (not } \\
\text { further } \\
\text { specified; PCR } \\
\text { testing } \\
\text { according to } \\
\text { CDC guidelines } \\
\text { mentioned) }\end{array}$ \\
\hline Lee 2020 (Korea) & $0.0 \%$ & 2 & 3 weeks & $\begin{array}{l}\text { All 123 staff at the } \\
\text { investigated long-term care } \\
\text { hospital }\end{array}$ & PCR \\
\hline $\begin{array}{l}\text { Grabenhorst 2020 } \\
\text { (Germany) }\end{array}$ & $0.0 \%$ & 4 & $\begin{array}{l}9.5 \\
\text { weeks }\end{array}$ & $\begin{array}{l}\text { All staff members at the } \\
\text { investigated nursing home } \\
\text { (no numbers provided) }\end{array}$ & PCR \\
\hline
\end{tabular}

Abbreviations: CDC, United States Centers for Disease Control and Prevention; CFR, case fatality rate; PCR, polymerase chain reaction 
Table 6: COVID-19 mortality rates among long-term care users and staff

\begin{tabular}{|c|c|c|c|c|c|c|}
\hline Study & $\begin{array}{l}\text { Mortality } \\
\text { rate of } \\
\text { all users } \\
\text { / staff }\end{array}$ & $\begin{array}{l}\text { Number } \\
\text { of users / } \\
\text { staff }\end{array}$ & $\begin{array}{l}\text { Number of } \\
\text { people } \\
\text { who } \\
\text { contracted } \\
\text { COVID-19 }\end{array}$ & $\begin{array}{l}\text { Number of } \\
\text { deaths } \\
\text { among } \\
\text { those who } \\
\text { contracted } \\
\text { COVID-19 } \\
\end{array}$ & Time period & Source population \\
\hline \multicolumn{7}{|c|}{ Mortality rate among long-term care users } \\
\hline $\begin{array}{l}\text { Diamantis } 2020 \\
\text { (France) }\end{array}$ & $17.1 \%$ & 140 & $\mathrm{~N} / \mathrm{A}$ & 24 & 1 week & $\begin{array}{l}\text { All residents at the long-term care facility. Note that } \\
\text { number of deaths was "more than } 24 \text { ". No case definition } \\
\text { was provided. }\end{array}$ \\
\hline Blain 2020 (France) & $15.2 \%$ & 79 & 38 & 12 & 6 weeks & All 79 nursing home residents (all were tested) \\
\hline Osterdahl 2020 (UK) & $9.5 \%$ & 21 & 10 & $2^{*}$ & 1 week & $\begin{array}{l}21 \text { out of all } 24 \text { residents at the investigated nursing } \\
\text { home }\end{array}$ \\
\hline Stall 2020 b (Canada) & $9.5 \%$ & 126 & 89 & 12 & 2 weeks & $\begin{array}{l}\text { All nursing home residents, assuming full occupancy of } \\
\text { 126-bed facility }\end{array}$ \\
\hline Patel 2020 (US) & $7.9 \%$ & 126 & 35 & 10 & 4 weeks & $\begin{array}{l}8 \text { symptomatic residents and } 118 \text { remaining residents } \\
\text { who consented to testing ( } 1 \text { resident refused) }\end{array}$ \\
\hline Graham 2020 (UK) & $6.7 \%$ & 313 & 126 & 21 & 2 weeks & $\begin{array}{l}\text { Appr. } 94 \% \text { of all residents at the time of systematic } \\
\text { testing (available and consented to testing) }\end{array}$ \\
\hline $\begin{array}{l}\text { Grabenhorst } 2020 \\
\text { (Germany) }\end{array}$ & $1.6 \%$ & 122 & 16 & 2 & 9.5 weeks & $\begin{array}{l}\text { All } 122 \text { residents at the nursing home at the time of } \\
\text { systematic testing }\end{array}$ \\
\hline Dora 2020 (US) & $1.0 \%$ & 99 & 19 & 1 & 3.5 weeks & All 99 residents at the facility at the time of outbreak \\
\hline Balestrini 2020 (UK) & $1.0 \%$ & 98 & 9 & 1 & 12 weeks & $\begin{array}{l}\text { All } 98 \text { residents at a long-term care facility that } \\
\text { conducted systematic testing }\end{array}$ \\
\hline Lee 2020 (Korea) & $0.0 \%$ & 193 & o & o & 3 weeks & $\begin{array}{l}\text { All } 193 \text { inpatients at the investigated long-term care } \\
\text { hospital who were exposed to an infected care worker }\end{array}$ \\
\hline Roxby 2020 (US) & $0.0 \%$ & 80 & 4 & o & 3 weeks & $\begin{array}{l}\text { All residents at the investigated assisted living facility } \\
\text { except for } 2 \text { index cases }\end{array}$ \\
\hline
\end{tabular}


Table 7: Incidence of hospitalisations among long-term care users and staff with COVID-19 diagnosis

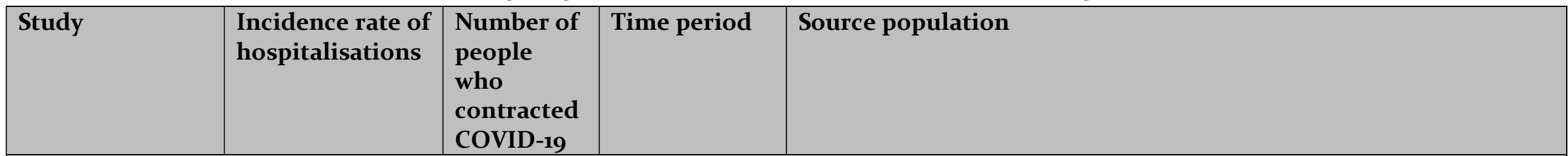

\section{Hospitalisations among long-term care users}

\begin{tabular}{|c|c|c|c|c|}
\hline $\begin{array}{l}\text { McMichael } 2020 \\
\text { (US) }\end{array}$ & $54.5 \%$ & 101 & 3 weeks & $\begin{array}{l}\text { All residents at the investigated skilled nursing facility who were } \\
\text { confirmed cases (not further specified; PCR testing according to CDC } \\
\text { guidelines mentioned) }\end{array}$ \\
\hline Mills 2020 c (US) & $42.9 \%$ & 7 & 14 weeks & $\begin{array}{l}\text { Confirmed cases among people receiving visiting medical care (no } \\
\text { systematic testing) }\end{array}$ \\
\hline Patel 2020 (US) & $37.0 \%$ & 35 & 4 weeks & Confirmed cases among 126 residents tested at outbreak facility \\
\hline $\begin{array}{l}\text { Yanover } 2020 \\
\text { (Israel) }\end{array}$ & $34.4 \%$ & 67 & Not reported & $\begin{array}{l}\text { Patients covered by Israeli health plan who had a SARS-CoV-2 positive } \\
\text { PCR test and who were nursing home residents }\end{array}$ \\
\hline $\begin{array}{l}\text { De Spiegeleer } \\
2020 \text { (Belgium) }\end{array}$ & $24.0 \%$ & 154 & 6.5 weeks & $\begin{array}{l}\text { All residents at the nursing home with clinical COVID-19 diagnosis or } \\
\text { positive PCR test }\end{array}$ \\
\hline Arons 2020 (US) & $19 \cdot 3 \%$ & 48 & 3.5 weeks & $\begin{array}{l}\text { All residents at the investigated skilled nursing facility with a positive } \\
\text { PCR test }\end{array}$ \\
\hline $\begin{array}{l}\text { Prieto-Alhambra } \\
2020 \text { (Spain) }\end{array}$ & $16.1 \%$ & 10795 & 4 weeks & $\begin{array}{l}\text { All patients included in a Catalan primary care database who are } \\
\text { nursing home residents and have a clinical COVID-19 diagnosis or } \\
\text { positive PCR test }\end{array}$ \\
\hline $\begin{array}{l}\text { Grabenhorst } 2020 \\
\text { (Germany) }\end{array}$ & $12.5 \%$ & 16 & 9.5 weeks & $\begin{array}{l}\text { All residents with a positive PCR test, identified through systematic } \\
\text { testing of all residents }\end{array}$ \\
\hline $\begin{array}{l}\text { McMichael } 2020 \\
\text { (US) }\end{array}$ & $6.0 \%$ & 50 & 3 weeks & $\begin{array}{l}\text { All health care personnel at the investigated skilled nursing facility who } \\
\text { were confirmed cases (not further specified; PCR testing according to } \\
\text { CDC guidelines mentioned) }\end{array}$ \\
\hline
\end{tabular}



with a positive PCR test 
medRxiv preprint doi: https://doi.org/10.1101/2020.06.09.20125237; this version posted August 1, 2020. The copyright holder for this preprint (which was not certified by peer review) is the author/funder, who has granted medRxiv a license to display the preprint in It is made available under a CC-BY-NC-ND 4.0 International license . 